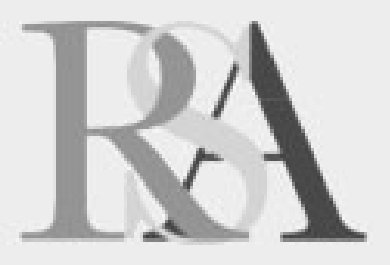

The Disappearance of an Author and the Emergence of a Genre: Niccolò da Poggibonsi and Pilgrimage Guidebooks between Manuscript and Print

Author(s): Kathryn Blair Moore

Source: Renaissance Quarterly, Vol. 66, No. 2 (Summer 2013), pp. 357-411

Published by: The University of Chicago Press on behalf of the Renaissance Society of America

Stable URL: http://www.jstor.org/stable/10.1086/671582

Accessed: 30/06/2014 03:11

Your use of the JSTOR archive indicates your acceptance of the Terms \& Conditions of Use, available at

http://www.jstor.org/page/info/about/policies/terms.jsp

JSTOR is a not-for-profit service that helps scholars, researchers, and students discover, use, and build upon a wide range of content in a trusted digital archive. We use information technology and tools to increase productivity and facilitate new forms of scholarship. For more information about JSTOR, please contact support@jstor.org.

The University of Chicago Press and Renaissance Society of America are collaborating with JSTOR to digitize, preserve and extend access to Renaissance Quarterly. 


\title{
The Disappearance of an Author and the Emergence of a Genre: Niccolò da Poggibonsi and Pilgrimage Guidebooks between Manuscript and Print*
}

\author{
by KATHRYN Blair MOORE
}

\begin{abstract}
While the anonymous Viaggio da Venetia al Sancto Sepolchro et al Monte Sinai, first published in Venice in 1518, was the most popular Holy Land guidebook in Renaissance Italy, the historical origins of the book have never been fully understood. From four illustrated versions of an earlier manuscript guide, the Libro d'Oltramare (1346-50), one can hypothesize about both the text and its author. The ultimate prototype for the Viaggio da Venetia was very likely one or more of these illustrated manuscripts, and the original author of both the text and illustrations was the Franciscan pilgrim Niccolò da Poggibonsi. Despite the eventual erosion of his name from the printed versions of the guidebook, the assertiveness and originality of the author parallels the production of other vernacular literature in mid-fourteenth-century Italy. Unlike Latin guidebooks of previous centuries, the intent to include illustrations that re-create the pilgrimage experience and the unprecedented descriptiveness of the prose together suggest that the book can be considered the foundational text for the genre of the illustrated pilgrimage guidebook.
\end{abstract}

\section{INTRODUCTION}

T n 1518 the Venetian editor Niccolò detto Zopino published the first edition of an anonymous Holy Land guidebook, the Viaggio da Venetia al Sancto Sepolchro et al Monte Sinai (Voyage from Venice to the Holy Sepulcher and to Mount Sinai), which was destined to be reprinted in over sixty editions until the final version of $1800 .{ }^{1}$ Although this printed book quickly became the most popular Holy Land guidebook in Renaissance Italy, modern scholars have shown little interest in its historical significance because of its anonymity, persistent confusion about its sources and

"I would like to thank Marvin Trachtenberg, Finbarr Barry Flood, and the anonymous readers for providing insightful critiques and suggestions. This research was assisted by a two-year Samuel H. Kress predoctoral Rome Prize and a New Faculty Fellows award from the American Council of Learned Societies, funded by the Andrew W. Mellon Foundation. All translations are mine, except where otherwise noted. $158-59$

${ }^{1}$ Poggibonsi, 1518. For a list of the editions of the Viaggio da Venetia, see Röhricht, 
precedents, and a bias against apparent unoriginality. By exploring the connections of the Viaggio da Venetia to related fourteenth- and fifteenthcentury manuscript copies of Niccolò da Poggibonsi's Libro d'Oltramare (1346-50), this article will reevaluate the current understanding of the genre of the illustrated guidebook written in the vernacular. ${ }^{2}$ The question of original authorship emerges as central to the understanding, not only of the multigenerational production of the anonymous Viaggio da Venetia, but also to the inception of the genre in the fourteenth century.

The genre of Holy Land pilgrimage accounts before the adoption of the vernacular in the fourteenth century was characterized by the repeated copying of previous Latin-language texts, which often resulted in accretive works of unknown or uncertain authorship. The origins of the genre ultimately lie in the fourth century, when textual accounts were first created by Christian pilgrims with the intent of allowing readers to visualize physical settings in relation to the corresponding narrative of the Bible. ${ }^{3}$ The earliest manuscript accounts have been compiled and translated by John Wilkinson, who counted only nineteen from the fourth until the eleventh century. ${ }^{4}$ After the Latin conquest of Jerusalem in 1099, these numbers dramatically changed. With a sudden influx of pilgrims from all of Europe, many new accounts appeared, which provide detailed descriptions of the geography and architecture of Palestine, Syria, and Egypt. ${ }^{5}$ These manuscript accounts continued to be copied throughout the early modern period and were even printed, beginning in the fifteenth century. ${ }^{6}$ In other words, although antecedent, the earlier genre continued to thrive, while also serving to highlight the novelty and modernity of the new works. The novel features of these new works, which constitute a new genre, include the adoption of the vernacular, the narrativization of the journey as told from the first-person perspective, detailed descriptions resulting from eyewitness encounters rather than from copying previous accounts, and (often but not always) the incorporation from the outset of pictorial illustrations. The remarkable number of printed books that describe pilgrimages to the Holy Land are catalogued in Reinhold Röhricht's Bibliotheca Geographica Palaestinae (Geographical Library of Palestine) of 1890. Röhricht's comprehensive catalogue surveys 1,599 accounts produced

\footnotetext{
${ }^{2}$ Poggibonsi, 1945 a.

${ }^{3}$ Frank, 102.

${ }^{4}$ Wilkinson, 1 .

${ }^{5}$ The most comprehensive survey of the accounts from this period, in both Latin and in Italian translation, can be found in Sandoli.

${ }^{6}$ Noonan.
} 
prior to the nineteenth century, the majority of which were created in the early modern period. ${ }^{7}$

The adoption of printing in the fifteenth century is an important factor in the broader dissemination and widespread appeal of early modern Holy Land guidebooks. Yet printing should not necessarily be credited as the primary catalyst in the formation of the new genre. A look to the fourteenth century, and particularly Franciscan culture, will help to clarify the motivations for these changes. This article traces the genesis of the Viaggio da Venetia to the Franciscan Fra Niccolò da Poggibonsi (fl. 134650), an intrepid and remarkably ambitious friar who braved shipwreck, pirate attack, and more than one abduction in order to make the spiritually salutary experience of pilgrimage available for those too poor or weak to make the physical journey. ${ }^{8}$ In the book that describes his journey of 1346-50 there are innovations characteristic of Franciscan culture, beyond the adoption of the vernacular. Despite a longstanding recognition among Franciscan scholars of the importance of the Libro d'Oltramare - the first pilgrimage guidebook written in the vernacular — its full significance has yet to be explored: as will be seen, this results from both the loss of the illustrated manuscript versions of the book and the failure to understand the connections of the original manuscript version to the printed books inspired by it. Ironically, the author's name became disconnected from the text as the book's popularity exploded in print, in the form of the Viaggio da Venetia. Although readers of the printed books were unaware of the author's identity, Fra Niccolò's function as an author certainly exceeds the limits of his fourteenth-century text.

When the origins of the Viaggio da Venetia are resituated in the context of the fourteenth century, an assertive individuality emerges from the original text that defied the generic structures of the genre of pilgrimage accounts - characteristics typical of the contemporary works of other vernacular authors. The originality of Niccolò da Poggibonsi's project in the fourteenth century continued to inform the popularity and authenticity of his text, both in itself and as an inspiration for other accounts. By exploring the connections of the Viaggio da Venetia to the original fourteenth-century manuscript versions of Niccolò da Poggibonsi's pilgrimage account, this article hopes to restore to the Franciscan friar his originary status in relation to the genre, while also acknowledging that his historical identity was not the essential factor shaping its development, in a way that reflects the necessity and flexibility of the author function in the early modern period.

${ }^{7}$ Röhricht.

${ }^{8}$ Poggibonsi, 1945a, 3, 5, 131. 


\section{Fra NoE's VIAGGIO DA VENETIA (1518-1800)}

The innovativeness of the author of the Viaggio da Venetia and the connections of the book to Franciscan culture have been obscured by persistent confusion regarding its origins. The printed versions of Fra Niccolò's account have consistently been dismissed as derivative, generally believed to have been created in the late fifteenth century by some unknown author from other printed guidebooks, rather than from earlier manuscript sources. One scholar, for instance, described the first printed edition as "not a masterpiece of originality." The book has particularly been overshadowed by the fame of one of the earliest printed Holy Land guidebooks, the Peregrinatio in Terram Sanctam (Voyage to the Holy Land), first published in Mainz in 1486. In 1483 the noble author of the Peregrinatio, Bernhard von Breydenbach (1440-97), took an artist, Erhard Reuwich, on his journey, in order to create pictorial illustrations that would complement his description of the Holy Land. Reuwich's depiction of Syria, Egypt, and Palestine in a single foldout panorama has been hailed in the modern literature as the first eyewitness illustration of the Holy Land. The woodcut illustrations of the Viaggio da Venetia, in contrast, have been dismissed as works of artistic fantasy, lacking the topographic accuracy that is so strikingly innovative in the Peregrinatio. ${ }^{10}$ The perceived inferiority of the various editions of the Viaggio da Venetia vis-à-vis the Peregrinatio was the basis of the common assumption that its text was not an original creation, but instead a debased version of Breydenbach's account. Hugh William Davies even went so far as to hypothesize that the anonymous author met Breydenbach during the latter's journey of $1483-84 .^{11}$ More generally, Breydenbach's printed guidebook has been regarded as the inaugural text for the entire genre of the illustrated guidebook, a status that will be reconsidered through an examination of the textual origins of the Viaggio da Venetia. ${ }^{12}$

Despite the pervasive assumption of a derivative relation between the 1486 Peregrinatio and the Viaggio da Venetia, neither the text of the book nor its woodcut illustrations bear any resemblance to Breydenbach's

\footnotetext{
${ }^{9}$ Serra-Zanetti, 124, who believed the author of the Viazo was the "Franciscan monk Noe Bianchi."

${ }^{10}$ See the introduction to the facsimile edition of the Viazo da Venesia, where the woodcuts are described as fantastical and typical of the genre of popular literature: Petrucci and Petrucci, i.

${ }^{11}$ Davies, v, who refers to the creator of the 1500 Viazo, the earliest printed version of Fra Niccolò's account.

${ }^{12}$ See, for instance, Betschart.
} 
Peregrinatio, the former work incorporating dozens of cities and buildings not found in the latter. The Viaggio includes descriptions and individual illustrations of remote sanctuaries, like the church at the Cave of the Patriarchs in Hebron, for instance, that are not found in the Peregrinatio. Likewise, the earliest printed version of the book, the Viazo da Venesia al Sancto Iherusalem, published in Bologna in 1500, like the later Venetian editions includes descriptions and illustrations of animals such as the elephant (figs. 1-2), also not found in the Peregrinatio. ${ }^{13}$ The issue is further confused by the fact that several illustrations not in the 1500 Viazo but added to the 1518 Viaggio and included in every later edition closely resemble the illustrations of Corfu, Modon, Crete, and Rhodes first published in the Peregrinatio. Unlike the panoramas in the Peregrinatio, the same images in the Viaggio da Venetia have been reduced to diminutive images presented across two pages, approximately one-sixth the size of Reuwich's panoramas. ${ }^{14}$ Moreover, the illustrations of Jerusalem, the Church of the Holy Sepulcher, and the Temple of Solomon were replaced by new illustrations in the 1518 Viaggio drawing on Reuwich's woodcut designs. ${ }^{15}$ Otherwise, the illustrations of the 1518 Viaggio have never been attributed to a known designer, and the woodcut illustrations of the 1500 edition remain attributed to the fanciful artistry of a certain Piero Ciza, whose name is inscribed in the frame of the title page of that edition. ${ }^{16}$

The question of the authorship of the Viaggio da Venetia seems to be resolved when we turn to the seventeenth-century editions, which were printed under the name of a certain Franciscan friar, referred to as "the reverend Fra Noe of the order of Saint Francis." The first known edition with this attribution was published in 1600 in Treviso. ${ }^{17}$ A Servite pilgrim with a similar name, Fra Noe Bianco, or Bianchi (d. 1568), made an account

${ }^{13}$ Poggibonsi, 1945a, 92. In addition to the elephant, he describes a giraffe, goat, and baboon. For the related fifteenth-century description and drawings of the elephant and giraffe by Ciracio d'Ancona, see Lehmann, 9-11. For the 1500 Viazo, see Poggibonsi, 1500 (hereafter cited as the 1500 Viazo).

${ }^{14}$ See Essling and Gèrard, 352-57.

${ }^{15}$ The illustration of Cairo is also replaced with a new two-page panoramic woodcut. Neither the woodcut's designer nor source is known, and the chronological relation to the first designs for Matheo Pagano's famous woodcut published around 1549 is also unknown: see Warner, Pagano, and Postel, 26-32.

${ }^{16}$ On Piero Ciza, see Essling and Gérard, 352-57.

${ }^{17}$ Poggibonsi, 1600. Nardone had identified the 1614 edition as the first with the author name Fra Noe: Nardone and Malherbe-Galy, 34. Copies of the 1600 Treviso edition can be found at the Spencer Collection of the New York Public Library and at the Bibliothèque nationale in Paris. 


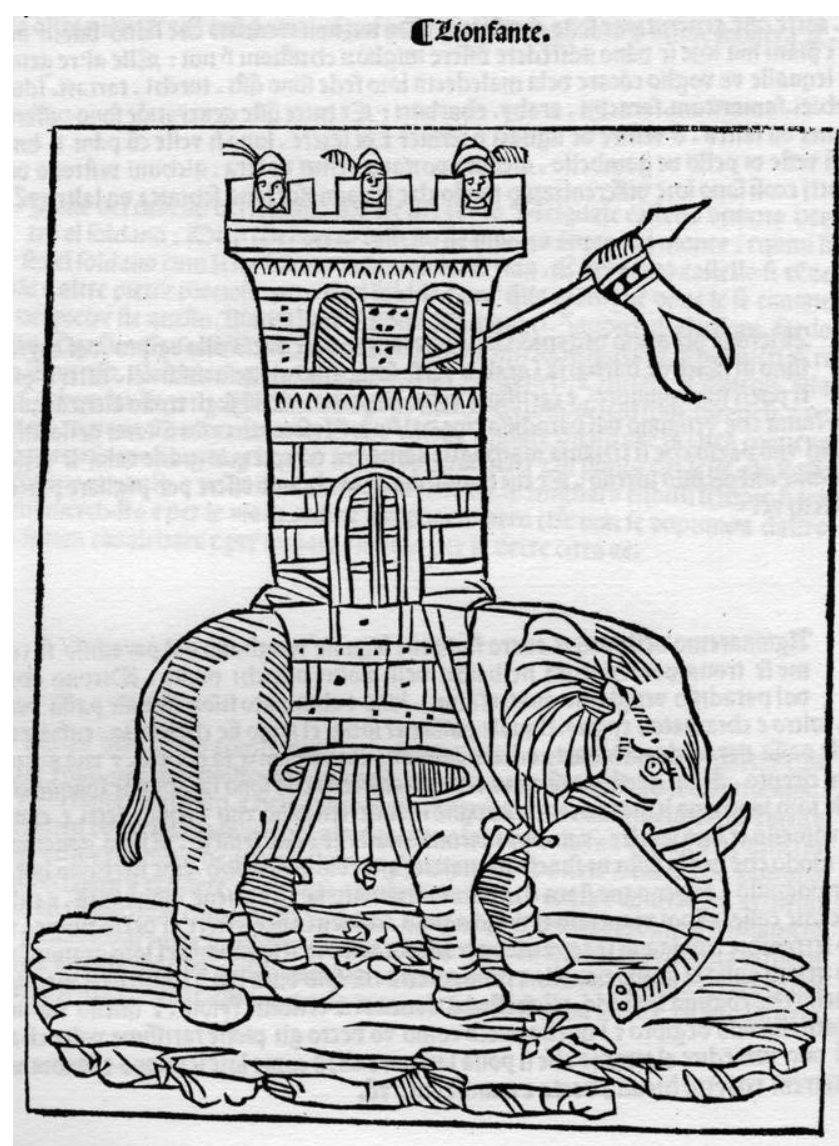

FIGURE 1. The elephant, Viazo da Venesia al Sancto Iherusalem. Bologna, 1500. Image from Viazo da Venesia al Sancto Iherusalem (Rome: Edizioni dell'Elefante, 1972).

of his journey of 1527: the resulting guidebook, first published in the second half of the sixteenth century, bears no resemblance to the Viaggio da Venetia. ${ }^{18}$ Although studies as recent as 1994 and 2007 continue to cite Noe Biancho or Bianchi as the author of the Viaggio da Venetia, Titus Tobler had already dismissed this attribution as a historical impossibility in the

${ }^{18}$ The real Noe Bianco's account of the Holy Land was first printed in the second half of the sixteenth century: see Bianco, 1566. In the dedicatory letter, addressed to Giulio Contarini, the author reports that he made his voyage in 1527. Röhricht, 181, cites several editions of this book: Venice: 1566, 1570, 1585, 1638, 1684; Bassano: 1638, 1697, ca. 1742. Other authors cite a 1556 edition. See Nardone and Malherbe-Galy, 33. 


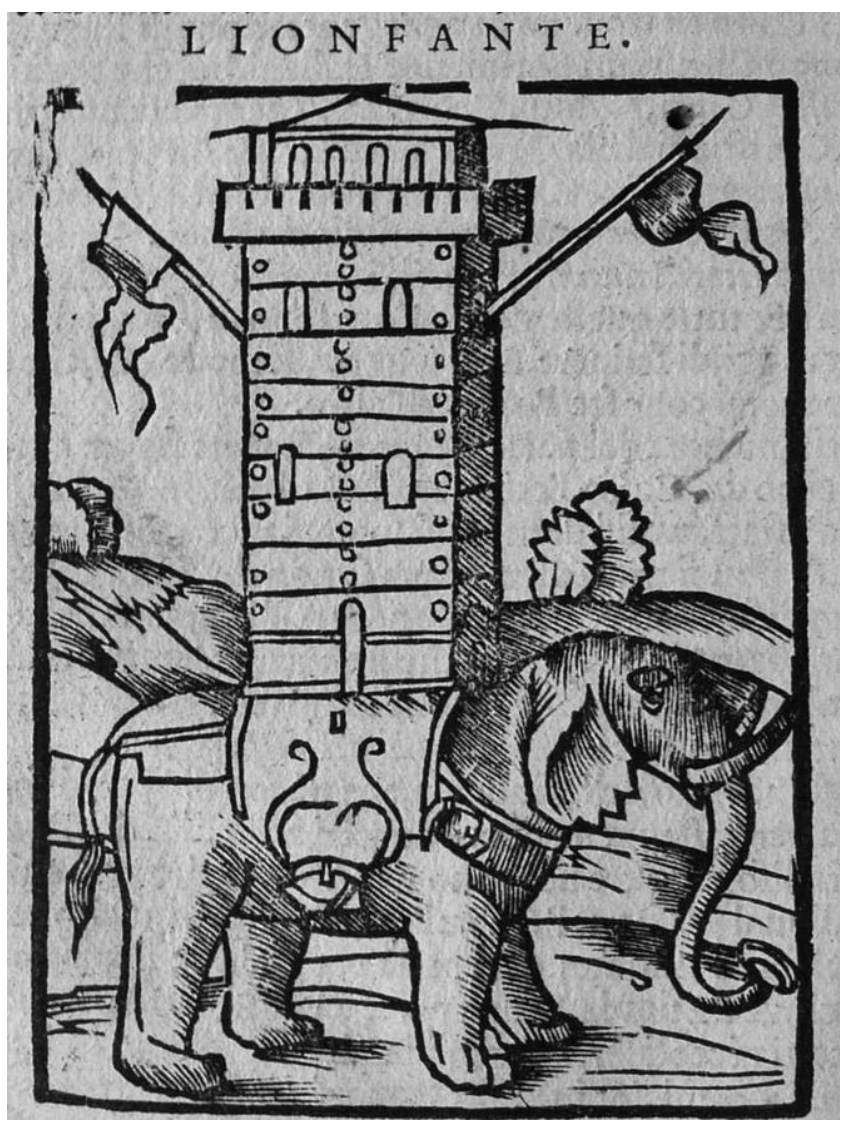

FIGURE 2. The elephant, Viaggio da Venetia al Santo Sepolcro et al Monte Sinai. Venice, 1606. Research Library, Getty Research Institute, Los Angeles (88-B1091).

nineteenth century. ${ }^{19}$ Despite this, many libraries and rare book collections continue to catalogue the various editions of the Viaggio da Venetia under the name of Noe Bianchi. It is not known whether the seventeenth-century editors formulated the name Fra Noe because they believed this Servite pilgrim had originally composed the Viaggio, or whether they simply wished readers to believe this. ${ }^{20}$ It is important to note that this Fra Noe

${ }^{19}$ For instance, Brefeld cited the Viazo da Venesia al Sancto Iherusalem under the author name Noe Bianchi. In 2007 an undated seventeenth-century edition of the Viaggio da Venetia was published as the work of Noe Bianco: see Bianco, 2007. See also Tobler.

${ }^{20}$ Nardone suggested that the author name Fra Noe was added in order to disassociate the book from Protestantism: Nardone and Malherbe-Galy, 43. 
is consistently identified as Franciscan in the seventeenth-century editions of the Viaggio. This identification suggests a possible awareness of the author's original identity, or, more likely, the fictive attribution acknowledges the unique role of the Franciscans as authorities regarding indulgences and pilgrimage in the Holy Land.

Amid the persistent confusion about both the author of the text and the designer(s) of the woodcut illustrations of the Viaggio da Venetia, an intriguing description of the author maintained at the very beginning of every edition, including that of 1500 , has been overlooked: "This voyage of the holiest Sepulcher of our lord Jesus Christ a worthy man wrote, who wanted to go with the help and willingness of the omnipotent God. And deliberately leaving from Venice, he wanted to write and at the same time draw all of the lands, ports, cities, [and] villages, from one place to the next through sea and through land. And at the same time he was drawing the churches and holy places that he found through all of his journey."21 This statement indicates that the original author produced the description of the pilgrimage from Venice to Jerusalem and the drawings of the buildings and cities he encountered simultaneously. This statement, like many anecdotes found in the first person throughout the book, has been ignored as fictive by modern scholars. ${ }^{22}$ Yet it is possible that the editors of the first editions of the Viaggio da Venetia believed that a single pilgrim had created both the text of the guidebook and its illustrations, even if they did not know his name.

\section{Niccolò dA Poggibonsi's Libro D'Oltramare} (1346-50)

In the early twentieth century, a scholar of Franciscan literature recognized that the text of the 1500 Viazo, like the 1518 Viaggio and subsequent editions, was in fact a version of the first Holy Land guidebook written in the vernacular, the fourteenth-century Libro d'Oltramare written by the Franciscan Fra Niccolò da Poggibonsi. Although Girolamo Golubovich made the assertion in his encyclopedic survey of Franciscan literature, many

\footnotetext{
${ }^{21}$ Petrucci and Petrucci, 3. See Appendix 1 for the Italian of this passage, quoted in its entirety.

${ }^{22}$ See, for instance, Serra-Zanetti, who dismisses this statement as an absurd fictionalization generated by the author, who "wanted us to believe that the woodcuts were based upon drawings executed by himself from life [dal vero] during his voyage (in the manner of modern journalists, furnished, however, with . . cameras!)": Serra-Zanetti, 125 .
} 
historians of printed books have remained unaware of it. ${ }^{23}$ Niccolò spent four years traveling from Venice to Jerusalem, Damascus, Cairo, and Alexandria, via Cyprus, and his first-person account of his travels was copied many times after his return to Tuscany in $1350 .{ }^{24}$ I have found four illustrated manuscript versions of Niccolò da Poggibonsi's Libro d'Oltramare dating from the fourteenth and fifteenth centuries, which suggest not only that the basis of the woodcut illustrations were these previous manuscript drawings, but also that the original creator of the illustrations may have been Niccolò da Poggibonsi himself. Compare, for instance, examples of the drawings of the elephant from two of these manuscripts with the same woodcut illustrations in both the 1500 Viazo and the 1606 Viaggio (figs. 1-4) ${ }^{25}$ In the narrative of Niccolò's journey, the detailed description of the elephant is found toward the end, in his eyewitness account of several exotic animals that he saw in Cairo. ${ }^{26}$

The detailed descriptiveness applied to all things encountered on his extraordinarily long journey — animals, people, buildings, and cities combined with the friar's emphasis on his personal experiences, always recounted in the first person, are unique features of the Libro d'Oltramare, without precedent in the Latin guidebooks of previous centuries. The originality of the eyewitness account and the author's expressed intent to accurately record all things encountered on the journey had persuaded Golubovich to believe that the lost autograph copy of the book must have

${ }^{23}$ Golubovich, i-xxviii. Golubovich believed that the author name Fra Noe found in the later editions of the Viaggio da Venetia may have been a shortened version of Niccolò da Poggibonsi's name. This is less likely considering that a section from Noe Bianco's Holy Land guidebook was added to the early seventeenth-century editions of the Viaggio da Venetia, which denotes the distances between locations on the journey. The 1600 edition, which is the first that I have found with the author name Fra Noe, is also the first to include this new table: see Nardone and Malherbe-Galy, 34.

${ }^{24}$ In the introduction to the English translation of the Libro d'Oltramare, one finds the most recent listing of known mss.: Poggibonsi, 1945a.

${ }^{25}$ Poggibonsi, 1606. A copy can be found at the Getty Research Institute.

${ }^{26}$ Poggibonsi, 1945a, 92: "The elephant is like this. He is black, all smooth without hairs; so big that he is a marvel to look at; he has no articulation save in the shoulders; the head is very large and the eyes so very small and red that they frighten the looker: the teeth are long and out of the mouth several braccia in length; the nose is long enough to reach the ground, several braccia in length; and with this he takes from the ground what he eats; the ears are fashioned like dragon wings; the tail is small; the feet are entirely round. The heavier the burden on his back the better he goes; and he carries on his back a wooden castle with thirty men inside, furnished with armour and stones and other things for battle. I saw one of their teeth which a merchant of Venice had bought at the cost of thirty-six gold glorins, which I measured, and it was thirteen of my spans long and was thick as a man's thigh; and so heavy that I could not even lift it off the ground." 


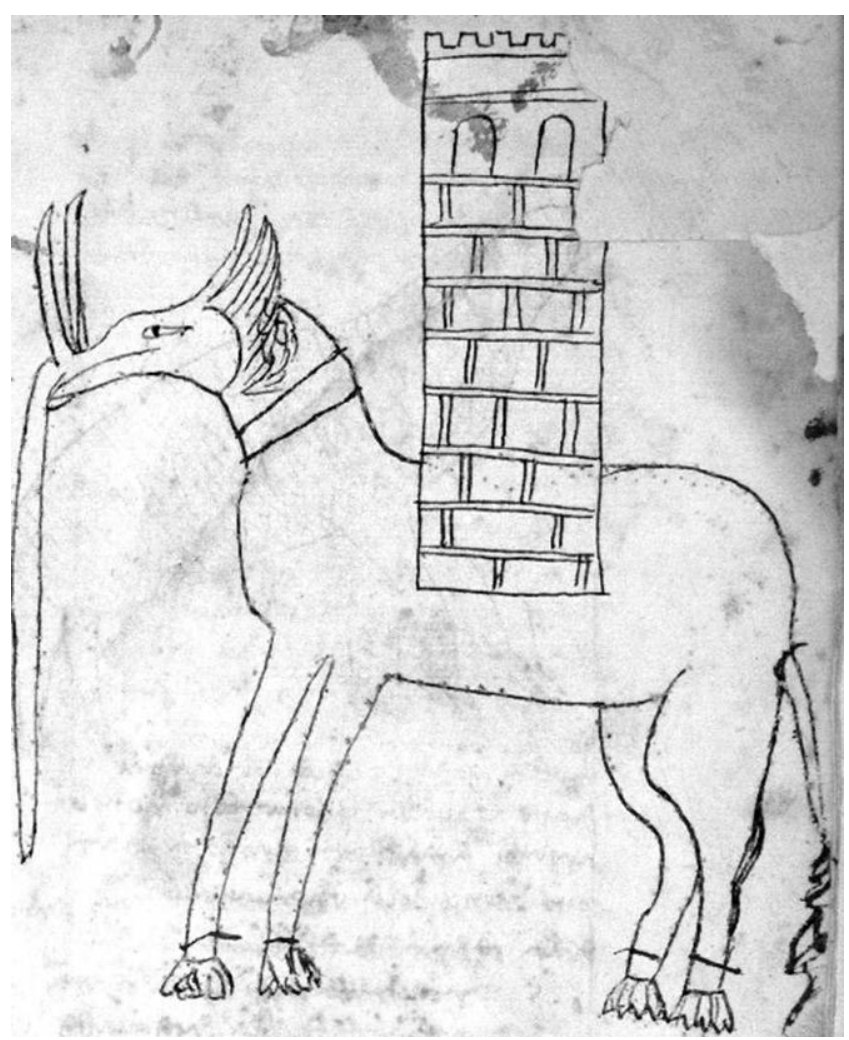

FIGURE 3. The elephant, BNCF II. IV. 101, fol. $41^{\mathrm{r}}$. Biblioteca Nazionale, Florence. By kind permission of the Ministero per i Beni e le Attività Culturali della Repubblica Italiana / Biblioteca Nazionale Centrale di Firenze.

contained drawings created by Niccolò da Poggibonsi during his journey. Without further evidence Golubovich was forced to conclude that "if the manuscripts with drawings had existed they were now lost."27 Golubovich's otherwise unsubstantiated hypothesis was easily refuted by Bellarmino Bagatti, who maintained in the introduction to the 1945 English edition that "it remains to be proved that Niccolò over and above his descriptions of the places, also made drawings of the places to adorn his book."

With the rediscovery of the illustrated versions of the guidebook, Bagatti's refutation of Golubovich no longer holds. Their rediscovery also allows us to understand the historical significance of a German manuscript

${ }^{27}$ Golubovich, xxviii.

${ }^{28}$ Poggibonsi, 1945a, xxvii. 


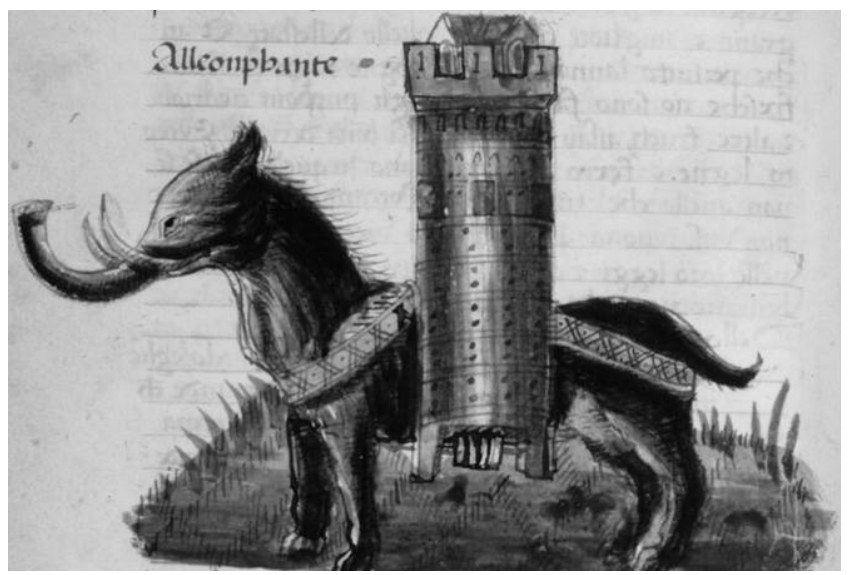

FIGURE 4. The elephant, NYPL Spencer 62, fol. 92 ${ }^{\mathrm{r}}$. Spencer Collection, The New York Public Library; Astor, Lenox and Tilden Foundations.

version of the same guidebook. In 1984, C. D. Cossar discovered that a fully illustrated, fifteenth-century German pilgrimage guidebook in the British Library was in fact a translation of the Libro d'Oltramare (BL Egerton 1900). ${ }^{29}$ The manuscript is dated by the British Library to around 1467: it was evidently created for another pilgrim, Gabriel Muffel, a patrician of Nuremberg who is said to have made his journey in $1465 .{ }^{30}$ Believing that no other illustrated versions had been made, Cossar argued that the German manuscript was the basis for the 1500 Viazo. ${ }^{31}$ BL Egerton 1900 postdates at least two of the newly found Italian illustrated versions (BNCF II. IV. 101

${ }^{29}$ Poggibonsi, Libro d'Oltramare, BL Egerton 1900 (hereafter BL Egerton 1900).

${ }^{30}$ The British Library Catalogue of Illuminated Manuscripts can be found online (http://www.bl.uk/catalogues/illuminatedmanuscripts/TourKnownF.asp), where BL Egerton 1900 is discussed by John Lowden as one of the "Treasures known and unknown in the British Library." In the catalogue the ms. is described as a German translation of Niccolò da Poggibonsi's Libro d'Oltramare, with the addition of 147 miniatures not found in the Italian version. Lowden argues that the woodcut illustrations of the 1500 Viazo could not have been based on the drawings of BL Egerton 1900 alone, concluding "that the Italian version with woodcuts printed at Bologna in 1500 was based on a lost model." Because BL Egerton 1900 includes illustrations of the cities, buildings, plants, and animals of Syria and Egypt not found in either Poggibonsi, Libro d'Oltramare, Ms. Panciatichi 78 (hereafter BNCF Panc. 78) or Poggibonsi, Libro d'Oltramare, Ms. Panciatichi 79 (hereafter BNCF Panc. 79), the German version must have been based upon either Poggibonsi, Libro d'Oltramare, BNCF II. IV. 101 (hereafter BNCF II. IV. 101) or Poggibonsi, Libro d'Oltramare, NYPL Spencer 62 (hereafter NYPL Spencer 62), if not a lost copy.

${ }^{31}$ Cossar. 
and BNCF Panc. 78); its illustrations closely correspond to the precedents in those earlier manuscripts. The more likely scenario is that the Italian illustrated manuscripts were the basis of both BL Egerton 1900 and the 1500 Viazo.

BL Egerton 1900 omits any mention of Niccolò da Poggibonsi; three of the four Italian illustrated versions, on the other hand, retain the author name. It seems remarkable that all of these manuscripts escaped the notice of modern scholars for so long. Alberto Bacchi della Lega created the first modern version of the text of Niccolò da Poggibonsi's guidebook in 1881, drawing on ten manuscripts in Florence. His sources included three of these illustrated versions - BNCF II. IV. 101, BNCF Panc. 78, and BNCF Panc. 79 of the Biblioteca Nazionale of Florence - but nowhere within the introduction or notes of his two-volume transcription are the drawings that he must have seen mentioned. ${ }^{32}$ This curious omission accounts for why scholars have assumed that all ten manuscripts were unillustrated. ${ }^{33}$ Indeed, when the first English translation of the Libro d'Oltramare was produced in 1945, T. Bellorini and Eugene Hoade never consulted all of these manuscripts, instead primarily relying on an unillustrated copy in the Library of St. Saviour's in Jerusalem, which was itself a copy of another manuscript in Perugia. ${ }^{34}$

One of these illustrated manuscripts was not known to Bacchi della Lega or Bellorini: Ms. 62 of the Spencer Collection of the New York Public Library has until now been misidentified as the Viaggio of Fra Noe or Noe Bianchi, because of its resemblance to the 1500 Viazo. ${ }^{35}$ This manuscript

${ }^{32}$ Poggibonsi, 1881, xi: "Codici Magliabechiani: 1. Classe XXXVIII no 47. . . . 2. Palchetto VIII, no 3 . . . 3. Palchetto IV, no II. IV. 101 . . . 4. Palchetto IV, no 119. . . Codici Palatini: 1. E. 5, 9, 7 . . 2. No 54, già Panciatichi... . 3. No 106, già Panciatichi... . Codici Riccardiani: 1. No 2819. . . . 2. No 2037. . . 3. No 1279." BNCF Panc. 78 was referred to as Ms. Palatino 106 in the Biblioteca Nazionale's former cataloguing system, while BNCF Panc. 79 was formerly referred to as Ms. Palatino 54.

${ }^{33}$ Besides Bacchi della Lega's study of 1881 (Poggibonsi, 1881), I know of only one other instance in which any of these ten mss. was directly studied by a nineteenth- or twentieth-century scholar, rather than just being cited as one of the known unillustrated mss. of Niccolò da Poggibonsi's guidebook. Francesco Poggi compared BNCF II. IV. 101 with a copy of Simone Sigoli's fourteenth-century pilgrimage account: see Poggi and Fiacchi, xxiv-xxxiii.

${ }^{34}$ Poggibonsi, 1945a, i. Besides the copy in the Library of St. Saviour's in Jerusalem, the other unillustrated copies of the Libro d'Oltramare that Bellorini consulted for the English translation include: a ms. transcribed by a Florentine who was born in Poggibonsi in 1413, a ms. dated 1512 also transcribed by a Florentine, and another copy dated 1459 .

${ }^{35}$ See Kup. In this book, the drawing of the Church of the Nativity at Bethlehem found in NYPL Spencer 62 is reproduced under the name of Fra Noe's Viaggio. 
lacks an author name and had never been identified as a copy of Niccolò da Poggibonsi's fourteenth-century guidebook. NYPL Spencer 62 does not contain a colophon, but its script closely relates to a manuscript dated to $1451 .^{36}$ Only two of the illustrated versions of Niccolò da Poggibonsi's guidebook can be precisely dated according to the inscriptions of their copyists: BNCF Panc. 78 (to 1453) and BNCF Panc. 79 (to 1481). ${ }^{37}$ BNCF II. IV. 101 appears to be the oldest of the surviving manuscripts, but like NYPL Spencer 62 it does not contain a colophon indicating its date of creation or the identity of the scribe. The end of BNCF II. IV. 101 contains various appendices (all in the same hand) including illustrations of different alphabets and an account of the indulgences of the churches of Rome, the latter also found in NYPL Spencer $62 .{ }^{38}$

Although all of the illustrated copies were produced on paper, unlike the later manuscript copies the text and drawings of BNCF II. IV. 101 were produced by the same hand, in the same pen without color wash. ${ }^{39}$ The script is idiosyncratic and at times almost illegible, formatted into two columns with most drawings tightly fitted within the width of a single column. In contrast, the three later illustrated manuscript copies are formatted into one block of ruled text, executed in a clear script, with large spaces left for an illuminator to add illustrations in both pen and color wash. Underneath some of the drawings of BNCF Panc. 79 it is still possible to see the faint handwriting indicating what illustration the artist should insert. ${ }^{40}$ In contrast, the drawings of BNCF II. IV. 101 are tightly embedded within the text and composed of shaky lines and awkward forms indicating the work of an amateur artist.

The unique features of BNCF II. IV. 101 present the possibility that it may be either the original version of the guidebook, or an immediate copy

${ }^{36}$ For the comparable script, see facsimile 199 in Thompson, 470.

${ }^{37}$ These inscriptions are transcribed in the catalogue of the Panciatichi mss., Ministero della pubblica istruzione, 132-34.

${ }^{38}$ The alphabets are found in NYPL Spencer 62 , fol. $59^{\mathrm{v}}$, while the account of the indulgences of the churches of Rome begins begins at ibid., fol. $60^{\mathrm{r}}$.

${ }^{39}$ The use of paper parallels another series of fourteenth-century manuscripts produced in a Franciscan context: the Meditationes Vitae Christi. Like the copies of the Libro d'Oltramare, pen and color wash on paper were employed — modest materials appropriate to the Franciscan vows of poverty and humility. Moreover, what is believed to be the autograph copy, Ms. Ital. 115 of the Bibliothèque nationale in France, was created around 1350, at the time of Niccolò da Poggibonsi's return to Italy. For the Meditationes, see Flora.

${ }^{40}$ See, for instance, fols. $77^{\mathrm{r}}, 88^{\mathrm{r}}$. The illustrations in which the writing is most visible are those that have no precedent in the previous copies, figural scenes involving either Moses or Niccolò's interpreter. 
of it. If BNCF II. IV. 101 was indeed produced by Niccolò da Poggibonsi himself after his return to Italy in 1350, then this would confirm the statement in the printed versions of the guidebook - first appearing in the 1500 Viazo - that asserts that the author simultaneously described and drew the holy sites during his journey to Jerusalem. A revealing statement made toward the end of the Libro d'Oltramare seems to confirm Niccolo's intent to record his experiences firsthand: "I have recounted the places of the monastery [of St. Catherine] as briefly as I could but of this writing I must be forgiven, because the things that one cannot so briefly describe and the other places [which I have already described] can provide some spiritual delight; and rather I have tired myself writing this, in order that one can better understand, [and so] I have represented [these places] as close as to how they are; although that I thought in my heart and decided in my mind to never leave from the place until I had seen everything as you find written. And in order to not fail I wrote day by day on a pair of gessoed tablets that I carried by my side." ${ }^{\prime 1}$ Golubovich argued that this statement reveals that "Niccolò had supplied his manuscript with pen drawings," and it is possible that BNCF II. IV. 101 was the autograph manuscript that Golubovich believed to have been lost. ${ }^{42}$

Several factors indicate that BNCF II. IV. 101 was produced in the Florentine orbit. By 1670 the manuscript was in the Strozzi Library in Florence, when a new binding and introduction were added. ${ }^{43}$ Niccolò's hometown of Poggibonsi, where a Franciscan establishment had existed since the thirteenth century, is a short distance from Florence; although nothing is known of the date or location of his death, it seems that his guidebook must have remained in Tuscany. ${ }^{44}$ The majority of the unillustrated copies were produced in Florence in the fifteenth and sixteenth centuries, and we also know for certain that BNCF Panc. 78 and BNCF Panc. 79 were copied in Florence in the mid-fifteenth century. The scribe of BNCF Panc. 78 writes that he copied "from the original itself' in 1453, suggesting that his source — hypothetically BNCF II. IV. 101 — was

${ }^{41}$ Author's translation from the Italian of BNCF II. IV. 101, fol. $41^{\mathrm{r}}$.

${ }^{42}$ Golubovich, 15. There are further indications within the text of accompanying drawings that Golubovich did not observe, like the chapter titles — for instance, "On the View of Venice" - frequently followed by imperatives asking the reader to "regard" a city or building: Poggibonsi, 1945a, 2.

${ }^{43}$ BNCF II. IV. 101, fol. ii: "Ex Bibliotheca Stroctiana Cod. 317. Petri Leopoldi M. E. D. munificentia nonis Julii 1786. Catalogus M. S. Codd. Stroctian.”

${ }^{44}$ Because Poggibonsi was contested between Florence and Siena, much of the archival material from the town has been lost. The Franciscan establishment in Poggibonsi was dedicated to San Lucchese: see Roncière. 
known in the fifteenth century as the autograph copy. ${ }^{45}$ The scribe of BNCF Panc. 79, working in 1481, identified himself as "a priest of Sant'Ambrogio of Florence," indicating that he was connected to the Benedictine church of Sant'Ambrogio in Florence. ${ }^{46}$

Both BNCF Panc. 78 and BNCF Panc. 79 are missing several of their original folios, so that it is difficult to definitively establish their relation. While the surviving parts of both dated copies closely correspond to the text and illustrations of BNCF II. IV. 101, both copies omit many of the illustrations in the latter part of the book describing the journey in Syria and Egypt. The drawings that are omitted - including the cities of Damascus, Alexandria, and Cairo, and the plants and animals of Egypt - are illustrated in BNCF. II. VI. 101, NYPL Spencer 62, BL Egerton 1900, the 1500 Viazo, and the 1518 Viaggio da Venetia. For this and other reasons it seems that BNCF Panc. 79 was an immediate copy of BNCF Panc. 78, while both BNCF Panc. 78 and NYPL Spencer 62 were apparently directly copied from BNCF II. IV. 101, or intermediary copies (fig. 5). BNCF Panc. 79 also includes several figural illustrations that are not found in other illustrated copies or printed versions, including a depiction at fol. $73^{\mathrm{v}}$ of Niccolò's interpreter being abducted by "Saracens" in the Arabian desert (fig. 6). ${ }^{47}$

Little is known about NYPL Spencer 62, since there is no copyist name, date, or location indicated. The original preface, written in the first person and in which Niccolò da Poggibonsi explains when and why he made his four-year journey through the Holy Land - found in BNCF II. IV. 101 and BNCF Panc. 78 - has been replaced in NYPL Spencer 62 with a vague introduction to the voyage to the Holy Land. Although the author's name has been omitted, this introduction, unlike those of the three other illustrated copies, includes a reference to the unnamed pilgrimauthor as "drawing every place as best one can." ${ }^{48}$ NYPL Spencer 62

${ }^{45}$ The format and content of both BNCF Panc. 78 and BNCF Panc. 79 are described in the catalogue of Panciatichi mss. See Ministero della pubblica istruzione, 132-34: "dal originale proprio."

${ }^{46}$ Ibid., 133-34, fol. 90 : "presibiterum Johannem magistri bartholomei iohannis pacis de colonnensibus cappellanum sancti ambrosii de florentia."

${ }^{47}$ The other figural illustrations in BNCF Panc. 79 are Niccolò and his companion at the Red Sea $\left(\right.$ fol. $73^{\mathrm{r}}$ ), Moses tending his sheep (fol. $77^{\mathrm{r}}$ ), Moses receiving the Ten Commandments (fol. $79^{\mathrm{r}}$ ), a pirate attack (fol. $88^{\mathrm{r}}$ ), and Niccolò's reuinion with his companion after an unfortunate separation (fol. $86^{\mathrm{r}}$ ).

${ }^{48}$ NYPL Spencer 62, fol. $1^{\mathrm{r}}$ : "[F] igurando ogni logo come meglio si potra." The first few folios of BNCF Panc. 79 are missing, although in the colophon the copyist refers to the book as the Liber santuarius de ultramare of Frate Niccholao de Poggibonizi, suggesting that the lost text retained mention of the author's identity. See Appendix 1. 


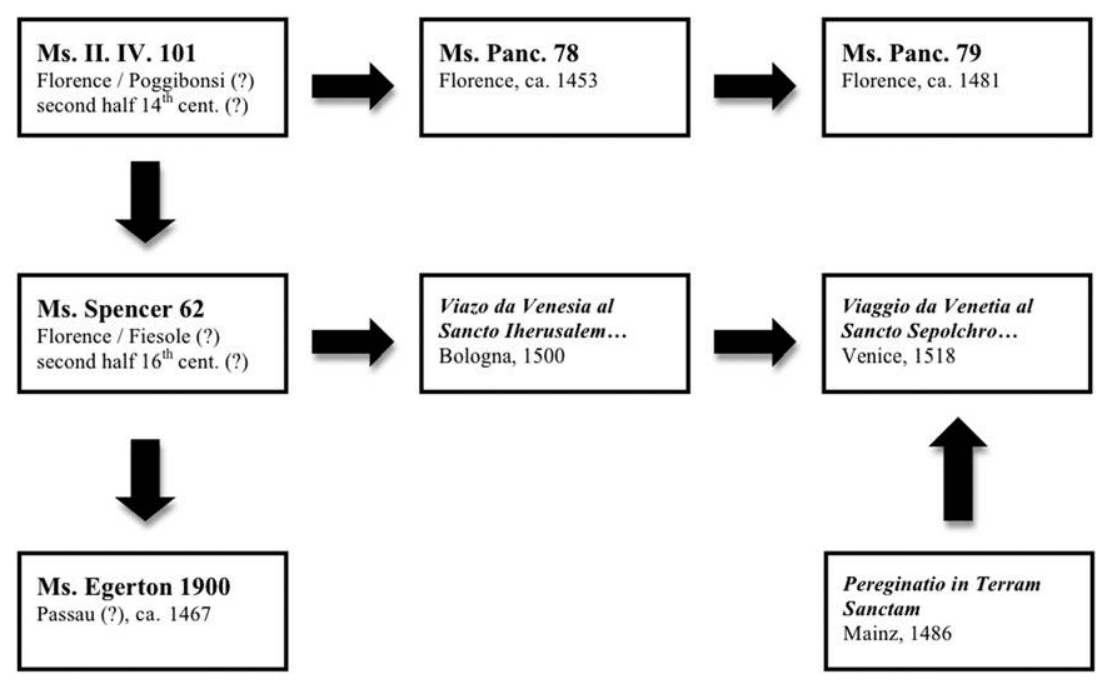

FIGURE 5. Hypothetical relations of the illustrated versions of Niccolò da Poggibonsi's Holy Land guidebook (author).

exhibits other unique features, including appendices on Rome and Fiesole (fols. $129^{\mathrm{v}}-136^{\mathrm{v}}$ ), the latter suggesting that the manuscript was probably also produced in Florence. The list of the pilgrimage sites in Rome is accompanied by drawings of St. Peter's, Castel Sant'Angelo, and the city of Rome (fols. $130^{\mathrm{v}}, 133^{\mathrm{r}}, 134^{\mathrm{v}}$ ). This is followed by a unique account of the indulgences gained from visiting certain places in Fiesole, illustrated by a double-folio drawing of that Florentine town (fols. $135^{\mathrm{v}}-136^{\mathrm{r}}$ ). ${ }^{49}$ Special mention is made of the cathedral dedicated to San Romolo in Fiesole; perhaps the scribe was connected to the Benedictine abbey there. $^{50}$

Unlike NYPL Spencer 62, BL Egerton 1900, and the 1500 Viazo, the three illustrated Italian manuscripts in the Biblioteca Nazionale of Florence (BNCF II. IV. 101, BNCF Panc. 78, and BNCF Panc. 79), like the majority of the unillustrated fifteenth- and sixteenth-century copies of Niccolò da Poggibonsi's guidebook, all retain the author's name. These

\footnotetext{
${ }^{49}$ There is also a final section on instructions for daily prayer, illustrated by a diagram of the days of the week (fol. 136 $6^{\mathrm{V}}$ ).

${ }^{50}$ NYPL Spencer 62 was purchased from L'Art Ancien for the Spencer Collection of the New York Public Library and accessioned on 9 April 1954. The manuscript's previous whereabouts are unknown.
} 
fepazri alla popadetta acjua ecotivenize pazecthi pazarimi es

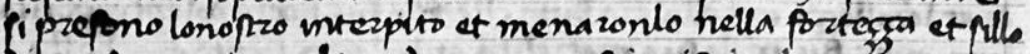
bimaniazono dovegli condureua quepti cripiani.

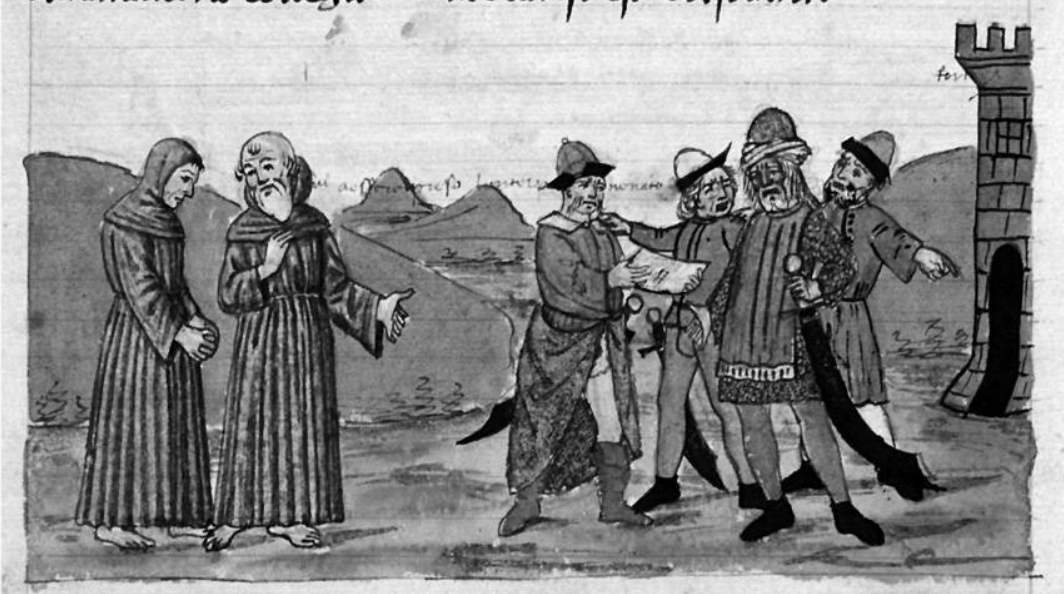

Et lointeaputo diffe come nmenaua a pancta catezina. Et lipazanni supono che apanita atezina none amidite impezonte guepta noneza ura anbe fiete pie mpezo be mai pezgilepo par

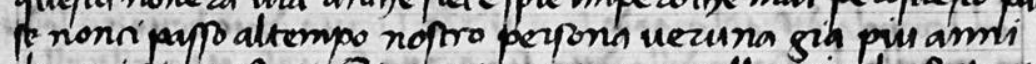

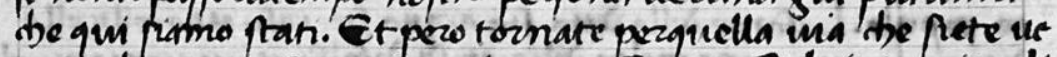
mut be perquefo pacpe noinompapperete. Et lointezpirogli moftro laletteza be not anaviomo dalpoldano et quept mata deti puzc cezcavano ditouaze cagione ado/b anoi. Or-inco mintiozono adizo quefa letteza tecuoi moptate pie falpa. Ozlapramo andazeogmi pazola fínalmente quepré paraini a pero menategli mbabillonia alpitiano. Allowa lonopra intez pito Jipk ziframi uedete quept pranin rivoghomo mena ze inbabillonia al plano. Ma tanto vidiro be pegtino nimenezan no alpliano io moftezzo laletteza ma. Etquanio lopldano

FIGURE 6. Niccolò's interpreter is abducted by Saracens, BNCF Panc. 79, fol. 73v Biblioteca Nazionale, Florence. By kind permission of the Ministero per i Beni e le Attività Culturali della Repubblica Italiana / Biblioteca Nazionale Centrale di Firenze.

manuscripts also retain an acrostic within the text that identifies Niccolò as the author. Niccolo explains that he created this acrostic, formed out of the initial letters of each chapter, beginning at the description of the Church of the Holy Sepulcher, so that no one else could claim to have 
written his book. ${ }^{51}$ A transcription of this particular passage from BNCF II. IV. 101, NYPL Spencer 62, the 1500 Viazo, and the 1518 Viaggio appears in Appendix 2, not only as an example of how the author's name has been omitted in the later versions, but also in order to compare the different dialects employed in each. Both BNCF II. IV. 101 and NYPL Spencer 62 employ the Tuscan dialect, albeit one of the fourteenth and one of the fifteenth century, while the 1500 Viazo employs a Bolognese dialect, which was then re-Tuscanized for the 1518 Viaggio.

\section{The VIAZO DA VENESIA AL SANCTO IHERUSALEM (1500)}

Almost every drawing found in the manuscript versions of the Libro d'Oltramare was transformed into a woodcut illustration in the 1500 Viazo. With the exception of the new illustrations discussed above, the woodcuts in the 1518 Viaggio were based upon those of the 1500 Viazo. Compare, for instance, the illustrations of Nazareth (figs. 7-10) as well as the church of Mount Sion (figs. 11-13) in BNCF II. IV. 101, BNCF Panc. 79, NYPL Spencer 62, the 1500 Viazo, and the 1606 edition of the Viaggio. The schemata for many of the illustrations that were established in the manuscript versions were replicated in the over sixty editions of the Viaggio da Venetia, including in the last edition of $1800 .^{52}$

But how was a series of Tuscan manuscripts transformed into an anonymous printed book in Bologna in the first place? All four of the Italian illustrated copies were written in the Tuscan vernacular. The text of the 1500 Viazo is, on the other hand, a transcription of the guidebook into the Italian vernacular of late fifteenth-century Bologna. The only additional text is found at the very end: a Latin letter written by a certain Giovanni Cola (Iohanne Cola) who dedicates the book to Giberto Pio, Prince of Carpi (1455-1500). ${ }^{53}$ Giberto is less famous as a patron of art and more as a man of arms, while his cousin, Alberto Pio III (1475-1531), is better known for his involvement in the courtly culture of the Estes at Ferrara. ${ }^{54}$ The dedicatory letter concludes with the name of the publisher,

\footnotetext{
${ }^{51}$ The letters form this acrostic: "Frate Nicolao: Frate Nicola di Corbico da Pocibonici del contado di Fiorenzca de la provincia di Toscana" ("Brother Nicolao: Brother Nicola di Corbico from Poggibonsi of the town of Florence of the province of Tuscany"). The capital letters at the beginning of each chapter have been left blank in BNCF II. IV. 101, presumably with the expectation that an illuminator would complete them.

${ }^{52} \mathrm{~A}$ copy of the 1800 edition can be found at the British Library.

${ }^{53}$ Petrucci and Petrucci, 85.

${ }^{54}$ See Sarchi, 129-46.
} 


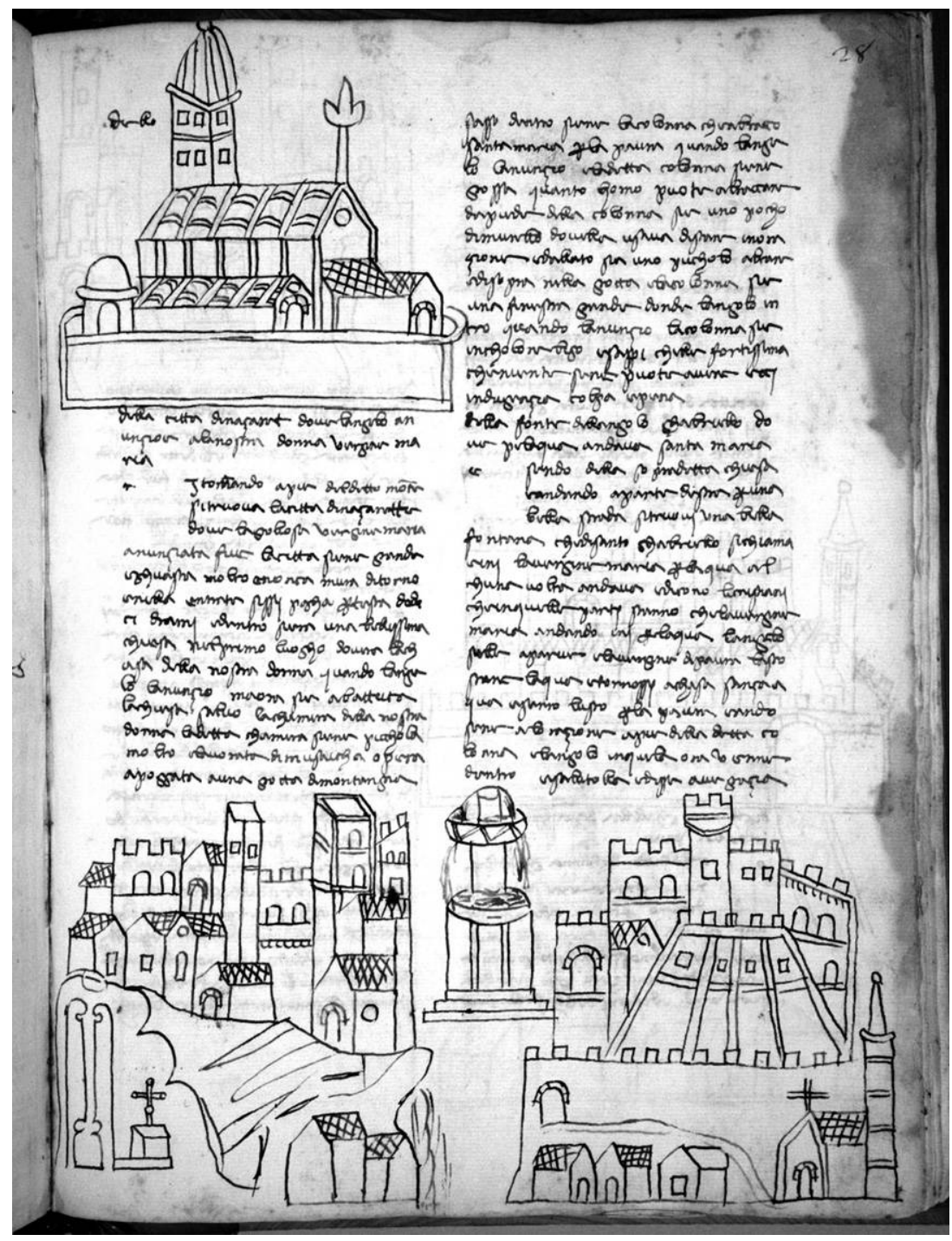

FIGURE 7. Nazareth (lower left) and fountain of the archangel Gabriel (lower right), BNCF II. IV. 101, fol. $28^{\mathrm{r}}$. Biblioteca Nazionale, Florence. By kind permission of the Ministero per i Beni e le Attività Culturali della Repubblica Italiana / Biblioteca Nazionale Centrale di Firenze. 


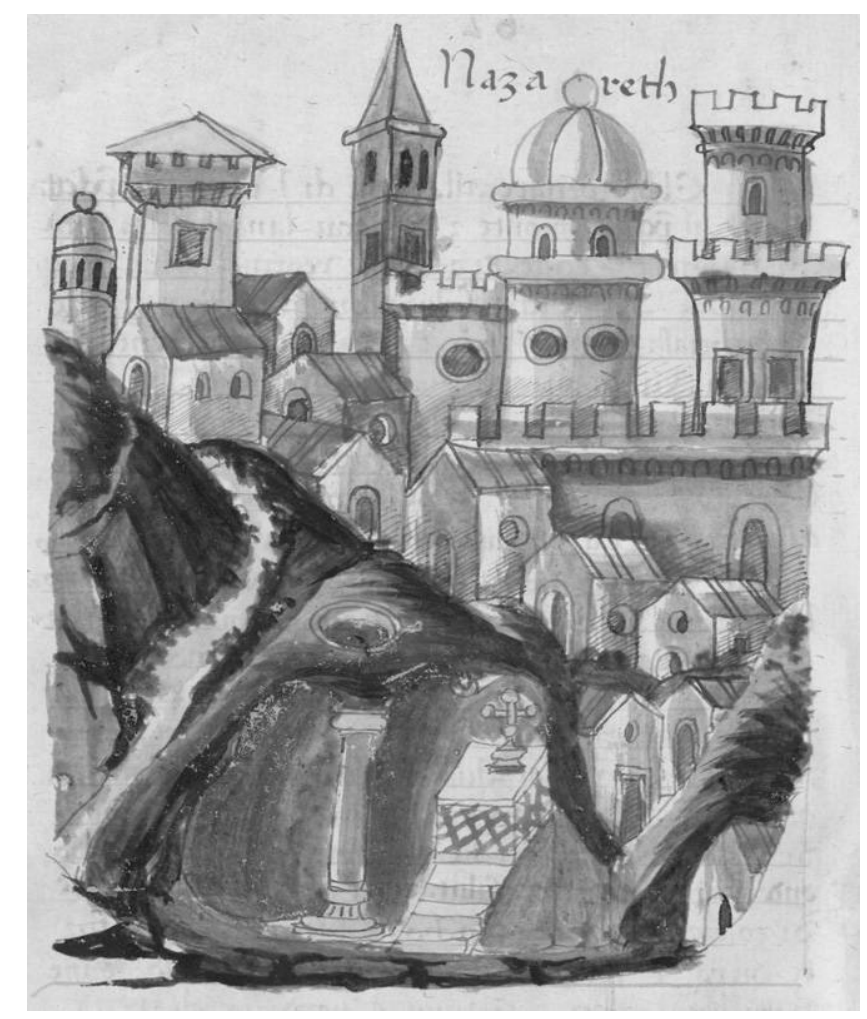

FIGURE 8. Nazareth, NYPL Spencer 62, fol. 61 ${ }^{\mathrm{v}}$. Spencer Collection, The New York Public Library; Astor, Lenox and Tilden Foundations.

Giustiniano da Rubiera (fl. 1495-1534), and the date of publication: 6 March $1500 .{ }^{55}$ Giberto had been captain of Bologna on behalf of the Bentivoglio family since 1484, but never spent much time in the city, traveling frequently to Mantua, Venice, Milan, and Ferrara. At the time of the Viazo's publication, Giberto was fighting on behalf of the Sforzas, and by May the war had concluded unfavorably for the prince, who was forced to sell Carpi to Ercole d'Este (1431-1505) in September. By the end of the month Giberto had died at Bologna of some unknown illness. ${ }^{56}$ Giovanni Cola (fl. ca. 1500) was the financer of the project to transform

${ }^{55}$ The family of Giustiniano came from Rubiera, thirteen kilometers from Reggio Emilia: Serra-Zanetti, 119.

${ }^{56}$ See Litta. 


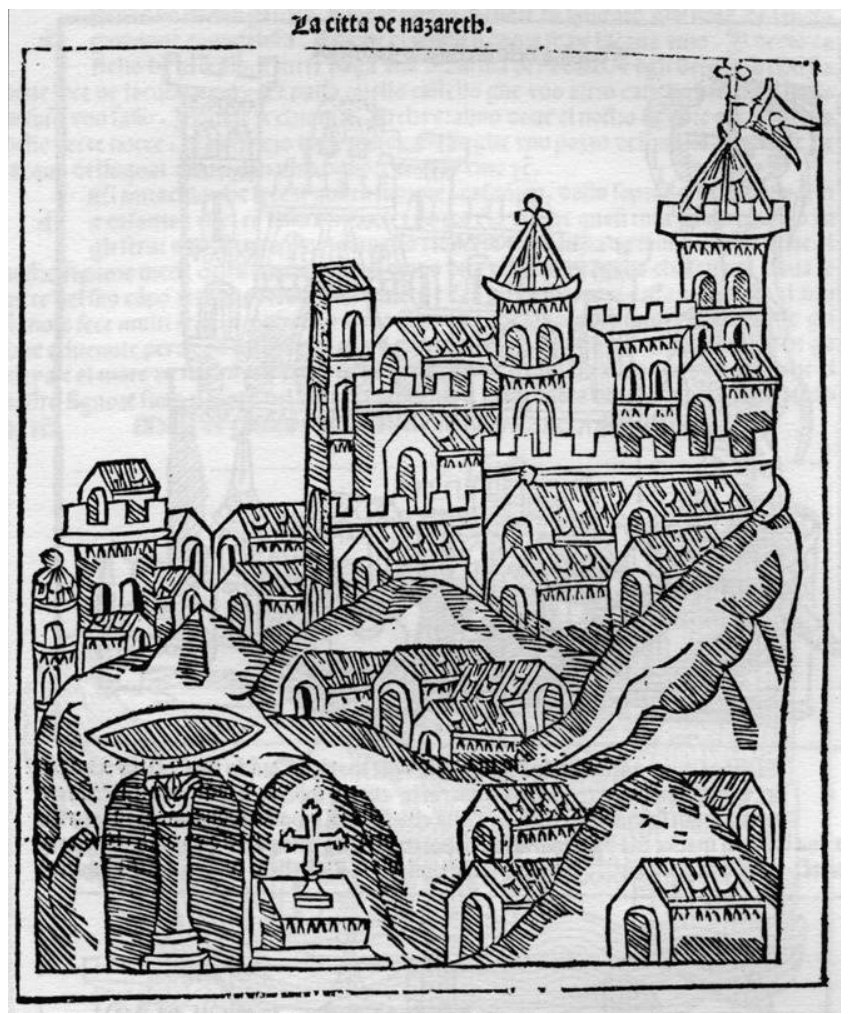

FIGURE 9. Nazareth, Viazo da Venesia al Sancto Iherusalem. Bologna, 1500. Image from Viazo da Venesia al Sancto Iherusalem (Rome: Edizioni dell'Elefante, 1972).

Niccolò da Poggibonsi's guidebook into a printed book, although little is known of him.

The publication of the Viazo was apparently beset with difficulties, besides the death of Giberto Pio in 1500. A year later, Giustiniano da Rubiera was forced to turn over all of his copies of the Viazo to Giovanni

${ }^{57}$ Despite the lengthy dedication letter, Giovanni Cola gives no other indications within the text of the 1500 Viazo of his position in Bologna or relation to Prince Pio da Carpi. Only one curious addition to the text provides a clue to his experiences and pretensions. This is found in the description of Zadar, where Giovanni not only includes a new description of the city's administration but also adds a reference to that city's men of letters as either learned or not. Giovanni specifically mentions Iacomo de Salupidio de la Marcha as being one of the very learned, while a certain Cristophoro is said to be "very presumptuous and the mirror of ignorance": see Petrucci and Petrucci, 5. According to Serra-Zanetti, 126, Giovanni Cola was from Pratello. 


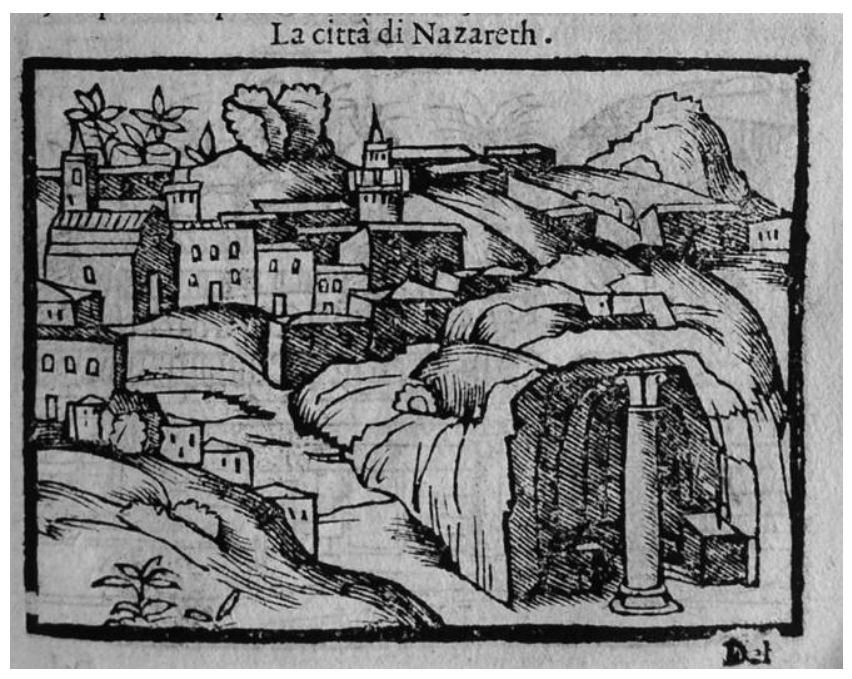

FIGURE 10. Nazareth, Viaggio da Venetia al Sanco Sepolcro et al Monte Sinai. Venice, 1606. Research Library, Getty Research Institute, Los Angeles (88-B1091).

Cola for some unknown reason. As a result, Giustiniano did not receive all of the hoped-for profits, leading to his near financial ruin. ${ }^{58}$ Interestingly, the historical moment when the original author's name was permanently removed from the text coincided with a new perception of that text as property to be owned and from which to derive financial gain. The convenient reproducibility offered by printing was undoubtedly a factor. Indeed, the punitive and possessive nature of Giovanni's action could be considered as symptomatic of a new conception of the value of books and authorship in the sixteenth century. ${ }^{59}$ Perhaps Giovanni Cola thought that his physical appropriation of the printed editions of the Viazo in some way let him also claim authorial rights. Despite the physical possession of the printed books, Giovanni was in some ways destined to fail, as authorial rights could not be similarly physically possessed. In all subsequent editions published in Venice, his name was absent. Niccolò da Poggibonsi had similarly failed to permanently conjoin his name to the book that he created, despite the acrostic he wove into it and the numerous passages asserting that he alone had created the text. These personalized elements were all too

${ }^{58}$ Serra-Zanetti, 126. The next book Giustiniano published came out in 1502, after two years of fighting bankruptcy.

${ }^{59}$ Loewenstein, $12-15$, who explores the historical implications of Foucault's argument that the modern idea of the author was linked to a new perception of discourses as "objects of appropriation" whose authors became subject to punishment: Foucault, 124. 


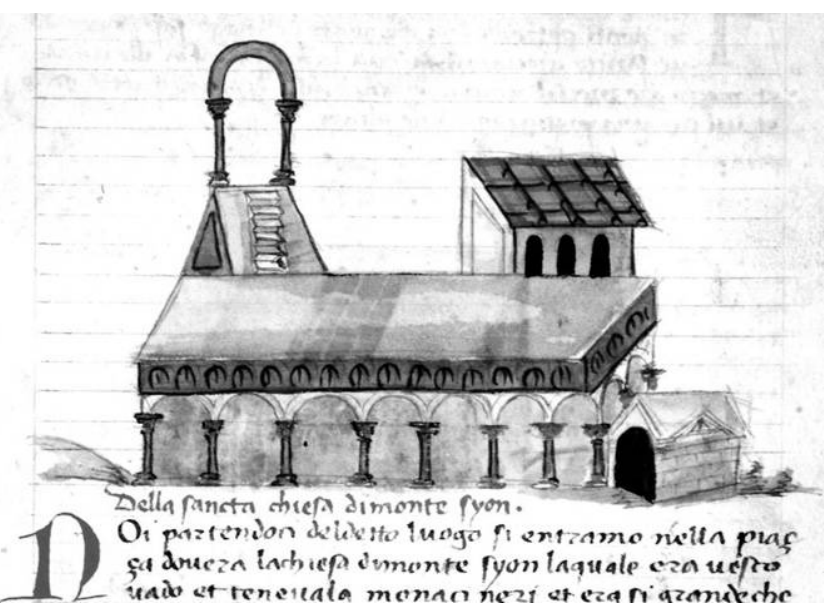

FIGURE 11. The church of Mount Sion, BNCF Panc. 79, fol. $22^{r}$. Biblioteca Nazionale, Florence. By kind permission of the Ministero per i Beni e le Attività Culturali della Repubblica Italiana / Biblioteca Nazionale Centrale di Firenze.

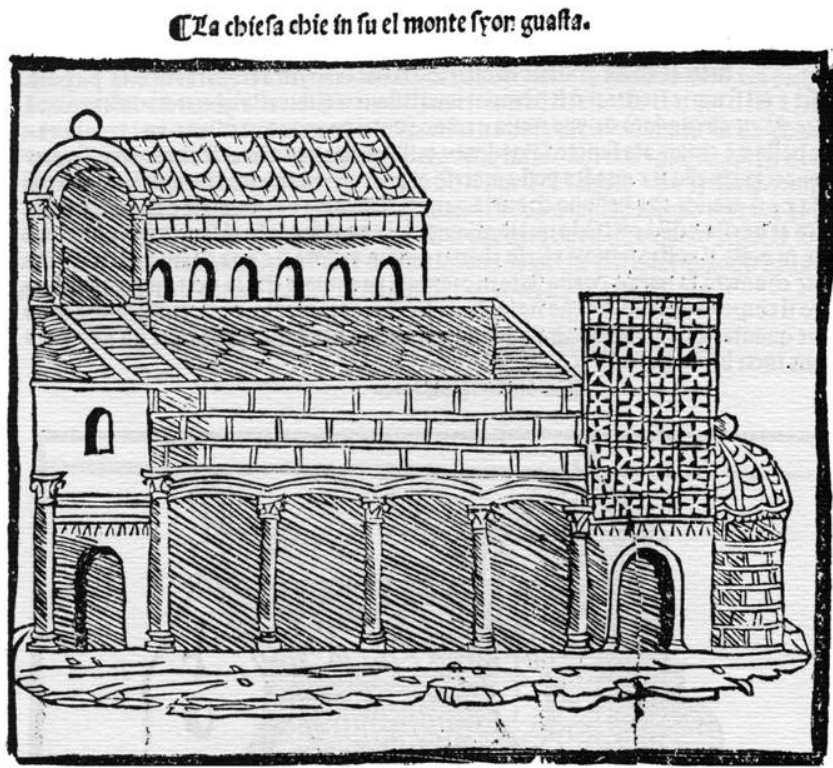

FIGURE 12. The church of Mount Sion, Viazo da Venesia al Sancto Iherusalem. Bologna, 1500. Image from Viazo da Venesia al Sancto Iherusalem (Rome: Edizioni dell'Elefante, 1972). 


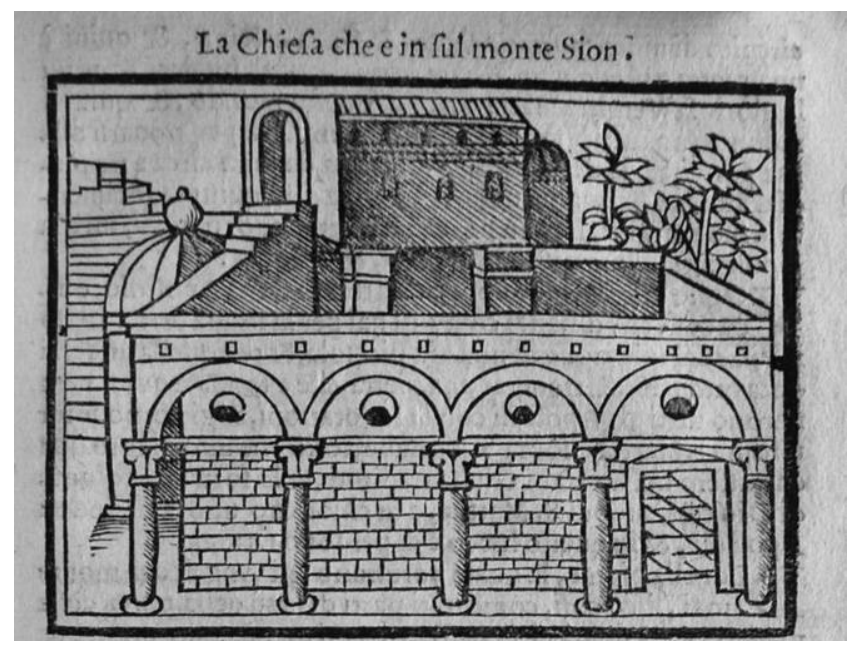

FIGURE 13. The church of Mount Sion, Viaggio da Venetia al Santo Sepolcro et al Monte Sinai. Venice, 1606. Research Library, Getty Research Institute, Los Angeles (88-B1091).

easily excised, as occurred with the creation of NYPL Spencer 62 and BL Egerton 1900. Indeed, Giovanni Cola may have been aware of the original author of the manuscript sources for the Viazo, and knowingly suppressed his identity in order to take possession of the book and potential profits.

After the printing of the Viazo in 1500, two separate traditions of Niccolò da Poggibonsi's Holy Land guidebook diverged, developing on independent trajectories: the anonymous printed versions that were illustrated and produced in the Veneto, and the unillustrated manuscript copies that continued to be produced in the sixteenth century in Tuscany. A similar disjunction exists in the modern literature, where the two traditions are studied separately. This is best demonstrated by the publication in 2007 of an undated edition of the Viaggio da Venetia al Sancto Sepulchro et al Monte Sinai. ${ }^{60}$ The introduction notes that the book was published around 1600 in Venice and that the original author was the Servite Noe Bianco. After a transcription of the Viaggio's text accompanied by reproductions of the original woodcut illustrations, a final note on the identity of the author states that the first edition of the book was published in 1518. The editors were apparently not aware of the 1500 Viazo published in Bologna, and also mistakenly believed that the Servite Noe Bianco had made his journey early in the sixteenth century. This modern edition is of great value, since

${ }^{60}$ Bianco, 2007. 
it makes more widely available the text and illustrations of one of the later editions of the Viaggio da Venetia; unfortunately, it will no doubt also contribute to the ongoing confusion about the authorship and historical origins of the book.

\section{The GERMAN Translation}

A different problem, one of interpretation rather than attribution, is evident in another study published in 2007, in which the 1533 edition of the Viaggio da Venetia is translated into French with extensive explanatory notes and a historical introduction by Jean-Luc Nardone and Jacqueline Malherbe-Galy. ${ }^{61}$ Unlike the Italian publishers of the undated edition, Nardone and Malherbe-Galy were aware of both the existence of the 1500 Viazo and its relation to Niccolò da Poggibonsi's Libro d'Oltramare. Their philological analysis was based upon the assumption that the 1500 Viazo was a translation of the German manuscript (BL Egerton 1900) into Italian, made in Bologna by Giovanni Cola. Their careful study of the relations between the texts of the Libro d'Oltramare, the illustrated German translation, the 1500 Viazo, and the 1533 edition of the Viaggio da Venetia can now facilitate comparison with the texts of the previously unknown illustrated manuscripts.

Cossar, who identified BL Egerton 1900 as a version of Niccolò da Poggibonsi's Libro d'Oltramare, proposed the possibility that the text of the 1500 Viazo was a translation of the German manuscript back into Italian, based on the evidence that its manuscript drawings closely resembles the woodcuts of the Viazo and that both versions of Niccolò da Poggibonsi's guidebook are anonymous. ${ }^{62}$ After a detailed philological analysis, Cossar was forced to conclude that this was not likely, but that instead a now-lost account of Muffel's journey, also in German, must have been the basis of the text of the 1500 Viazo. ${ }^{63}$ NYPL Spencer 62 is illustrated with the same drawings and is also an anonymous copy, unlike BNCF II. IV. 101, BNCF Panc. 78, and BNCF Panc. 79. Many of the textual variations between the manuscripts of the Libro d'Oltramare and the Viazo that Nardone and

${ }^{61}$ For the translation, see Nardone and Malherbe-Galy, 45-231.

${ }^{62}$ Cossar's arguments were expanded in a German doctoral dissertation presented in 1994 to the Universität Zürich: Betschart, 1996. Betschart was also not aware of the illustrated Italian mss. of Niccolò da Poggibonsi's Libro d'Oltramare. The book includes reproductions of several of the ms. illustrations from BL Egerton 1900, as well as woodcuts from the 1500 Viazo and later editions of the Viaggio da Venetia.

${ }^{63}$ The same conclusion has been reached by Lowden (see entry on BL Egerton 1900 in the online catalogue of mss. of the British Library). 
Malherbe-Galy ascribe to the intervening role of the German translation can instead be accounted for by variations in NYPL Spencer 62.

Many of the textual variations evident in BL Egerton 1900 are also found in NYPL Spencer 62, which was not known to Nardone and Malherbe-Galy. For instance, in BNCF II. IV. 101 and the unillustrated copies of the Libro d'Oltramare, Jerusalem is said to have been besieged for seven years by Vespasian by six legions of cavalry, while NYPL Spencer 62 refers to seven legions of men (sette legioni de populo), as does BL Egerton 1900 and the 1500 Viazo (sette lege di populo). ${ }^{64}$ While Malherbe-Galy argued that the change in terminology in the 1500 Viazo resulted from the modifications made to the German version, it is clear that the variation could also have resulted from a common relation to NYPL Spencer $62 .^{65}$ There are also some important variations among all of the illustrated versions that more directly suggest that NYPL Spencer 62, rather than BL Egerton 1900, may have been the link between BNCF II. IV. 101 and the 1500 Viazo. For instance, in the description of the place where the twelve apostles made the Credo in Deum, the text of BNCF II. IV. 101 and the unillustrated copies describe the place as a sloping descent with a great stairway (scala). In NYPL Spencer 62 the same place is described as a descent into un soclo, apparently a confusion of stairway (scala) and ditch (solco). ${ }^{66}$ In the 1500 Viazo this becomes a ditch (uno solco). ${ }^{67}$ BL Egerton 1900 omits this description. Likewise, in the description of the four columns that bewail the death of Christ in the Church of the Holy Sepulcher, a similar variant in the text of the 1500 Viazo perhaps resulted from a misreading of NYPL Spencer 62. While BL Egerton 1900, BNCF II. IV. 101, and the unillustrated

${ }^{64}$ NYPL Spencer 62, fol. $8^{\mathrm{v}}$.

${ }^{65}$ There are many other similar examples. In the description of the choir at the center of the Church of the Holy Sepulcher, the term tribuna is used in the unillustrated versions of the Libro d'Oltramare, while tribunale is used in both the 1500 Viazo and BL Egerton 1900: see Poggibonsi, 1945b, 21; Petrucci and Petrucci, 12. The term tribuna is used in BNCF II. IV. 101, but tribunale is used in NYPL Spencer 62. Likewise, in BNCF II. IV. 101 and the unillustrated copies of the Libro d'Oltramare Jerusalem is referred to as being in a valley with water coming from a river in Ebron (Hebron), while in NYPL Spencer 62, BL Egerton 1900, and the 1500 Viazo this becomes Boon or Beon: see Poggibonsi, 1945b, 11; Petrucci and Petrucci, 8. One final example is from the description of the field where St. Peter wept (Galicantus): BNCF II. IV. 101, BL Egerton 1900, and the unillustrated versions refer to a grotto (una grotto). The 1500 Viazo strangely refers to uno channicieto, o vero pantaneto: see Poggibonsi, 1945b, 41; Petrucci and Petrucci, 23. Perhaps the confused reading was caused by the transformation of una grotto into una grippa in NYPL Spencer 62. For Nardone's interpretation of the same passages, see Nardone and Malherbe-Galy, 66, 74, 94.

${ }^{66}$ NYPL Spencer 62, fol. $29^{\mathrm{v}}$.

${ }^{67}$ See Poggibonsi, 1945b, 41; Petrucci and Petrucci, 23; Nardone and Malherbe-Galy, 27. 
copies describe a door with an arched vault (una porta ad arco volta), the 1500 Viazo strangely refers to una messa. In NYPL Spencer 62 we find that the arched door is described as a porta messa in volta, perhaps misread as una messa. ${ }^{68}$

Despite these indications, there remains a curious reference in the 1500 Viazo not found in any of the surviving Italian manuscript copies, including NYPL Spencer 62, which seems to directly connect to BL Egerton 1900. In the description of the Dalmatian port of Zara (Zadar in modern-day Croatia), Giovanni Cola adds that the city is like Passau on the Danube and Nile (como Pastania nel Danubio el Nillo); in BL Egerton 1900 the city is compared to Passau on the Danube and Inn, while in NYPL Spencer 62 there is no such comparison. ${ }^{69}$ Moreover, there are other additions to the description of Zara in the 1500 Viazo that have no precedent in BL Egerton $1900 .^{70}$ If this was not a common comparison, then perhaps Giovanni Cola had multiple manuscript sources when he created the Viazo, including BL Egerton 1900 and NYPL Spencer 62. ${ }^{71}$

When we turn to the woodcut illustrations in the 1500 Viazo, we can likewise see that the drawings in BL Egerton 1900 could not have been the only source for Piero Ciza. One example is the Porta Aurea (Golden Gate): in all four illustrated Italian manuscripts, the structure is represented in frontal elevation as a square, crenellated building with two arched entryways and a window between (figs. 14-17). The same illustration in BL Egerton 1900 — still evident as an underpainting — has been painted over as a pink building with crumbling walls and narrow windows. ${ }^{72}$ Another example is

${ }^{68}$ NYPL Spencer 62, fol. $16^{\mathrm{v}}$.

${ }^{69}$ Nardone and Malherbe-Galy, 27. Petrucci believed that this statement in the Viazo was an error, indicated by the inclusion of reference to the Nile.

${ }^{70}$ There is only one curious addition to the text of the guidebook, which suggests Cola was personally familiar with the Venetian-controlled city of Zadar, in modern Croatia. Zadar (or Zara) had not been a part of Niccolò da Poggibonsi's journey, but in NYPL Spencer 62 and BL Egerton 1900 there is a small passage describing this city, between the account of Pola (in Yugoslavia) and Modone (in Greece): Petrucci and Petrucci, 4-5. These strange, personal references might relate to Giovanni Cola's experiences in Zadar, which in the fifteenth century was under the dominion of the Venetian Republic. At the time of Niccolò da Poggibonsi's journey, Zadar was more tenuously controlled by the Venetians, and local turmoil, including the uprising of 1346-47, may have specifically prevented him from stopping there.

${ }^{71}$ Another possibility is that the close correlation of certain elements of the texts of NYPL Spencer 62, BL Egerton 1900, and the Viazo result from a now-lost illustrated copy that was a common source.

${ }^{72}$ For the drawings of the Templum Salamonis and Templum Domini in BL Egerton 1900 , see Cossar, plates 3-4. This underpainting is noted in the online catalogue of the mss. of the British Library, where it is compared to the woodcut in the 1500 Viazo. Lowden, without knowing of the related illustrated Italian mss., reached the same conclusion that the final drawing in BL Egerton 1900 could not have been the basis of the 1500 Viazo. 


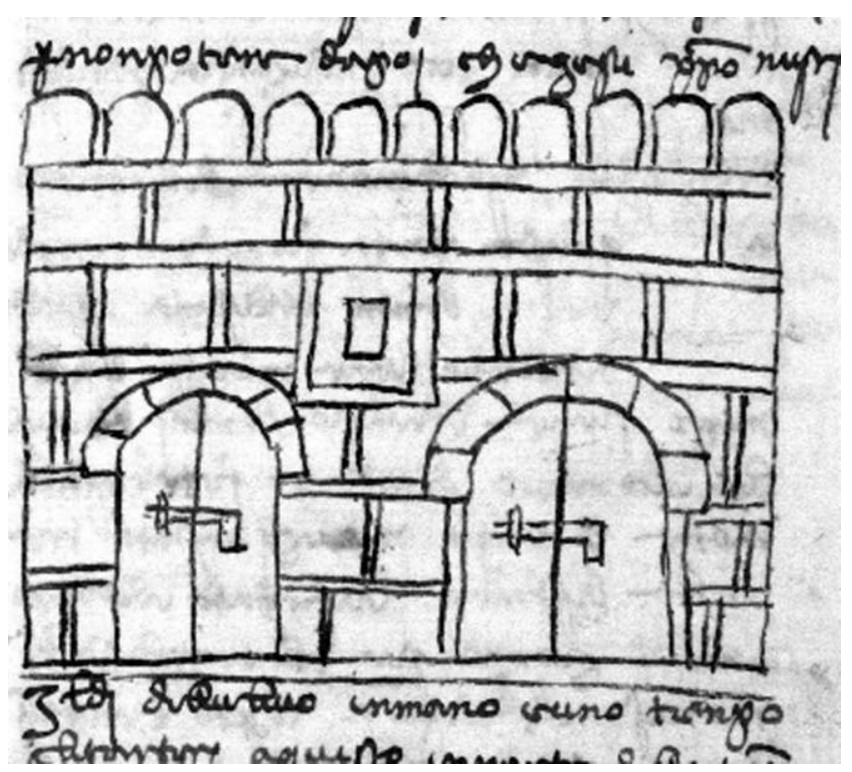

FIGURE 14. Golden Gate, BNCF II. IV. 101, fol. 20r . Biblioteca Nazionale, Florence. By kind permission of the Ministero per i Beni e le Attività Culturali della Repubblica Italiana / Biblioteca Nazionale Centrale di Firenze.

the illustration of the Templum Salamonis (Temple or Palace of Solomon) and Templum Domini (Temple of the Lord), together forming the illustration of the Tempio di Salamone (Temple of Solomon): in BNCF II. IV. 101 (fig. 18), BNCF Panc. 78, BNCF Panc. 79, NYPL Spencer 62 (fig. 19), the 1500 Viazo (fig. 20), and the 1518 Viaggio these two buildings are represented in a single illustration. ${ }^{73}$ In BL Egerton 1900, however, the illustration is separated into two independent drawings located back-to-back on a folio. ${ }^{74}$ These are just two examples of the variations between the illustrations of BL Egerton 1900 and the 1500 Viazo that suggest that the illustrated Italian versions of the Libro d'Oltramare were probably the source for the woodcuts of the printed book, rather than the German translation.

\footnotetext{
${ }^{73}$ For an analysis of the drawings of the Temple of Solomon in relation to representations of the Dome of the Rock in Italian visual culture, see Moore.

${ }^{74}$ Brefeld includes many illustrations from BL Egerton 1900, including those of Venice (20), Jerusalem (25), the ostrich (67), and the Golden Gate (196).
} 


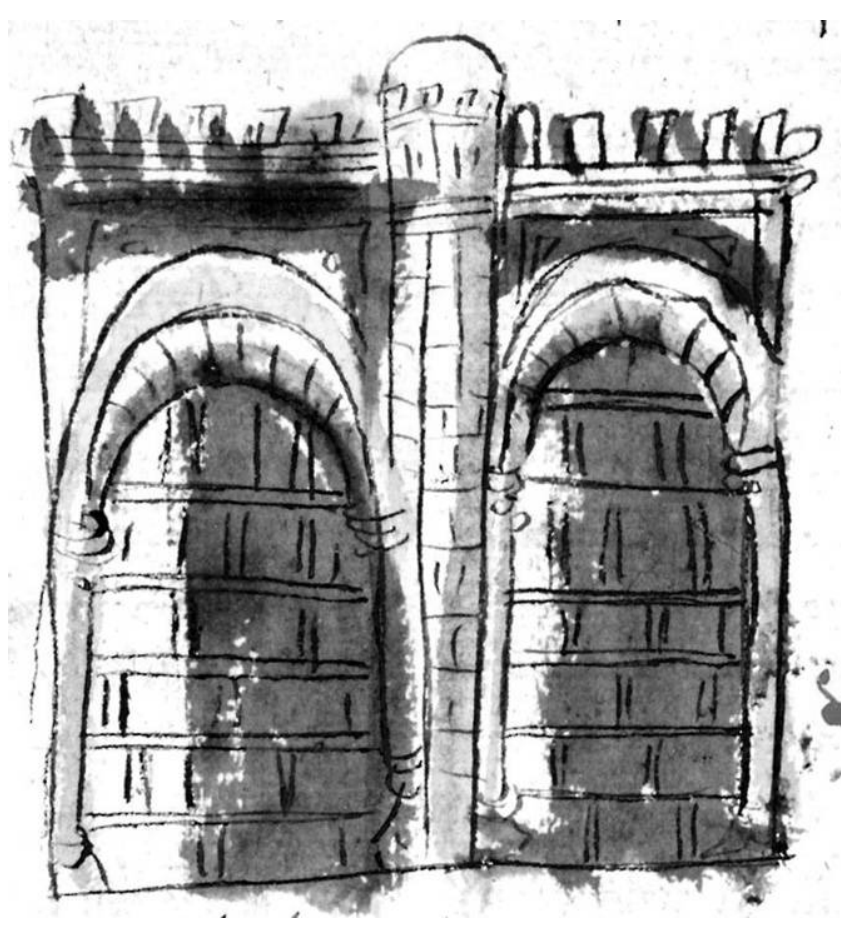

FIGURE 15. Golden Gate, BNCF Panc. 78, fol. 8v . Biblioteca Nazionale, Florence. By kind permission of the Ministero per i Beni e le Attività Culturali della Repubblica Italiana / Biblioteca Nazionale Centrale di Firenze.

\section{Later Editions of the ViagGio da VENETia}

Although the format of the guidebook was entirely reconceived for the 1518 edition printed in Venice, many of the illustrations continued to be connected to the woodcut illustrations of the 1500 Viazo. The scale and conception of the illustrations have been so modified that this relation is not immediately evident. While the woodcut illustrations of the 1500 Viazo employed the same conventions of pictorial representation first established in the fourteenth-century version (BNCF II. IV. 101), one-point perspective, shading, and a continuous background landscape have been added to many of the illustrations of the 1518 Viaggio (see figs. 7-13). ${ }^{75}$ While the name of

${ }^{75}$ There are also new illustrations of animals based upon Breydenbach's Peregrinatio added to the sixteenth-century Viaggio da Venetia: see Nardone. 


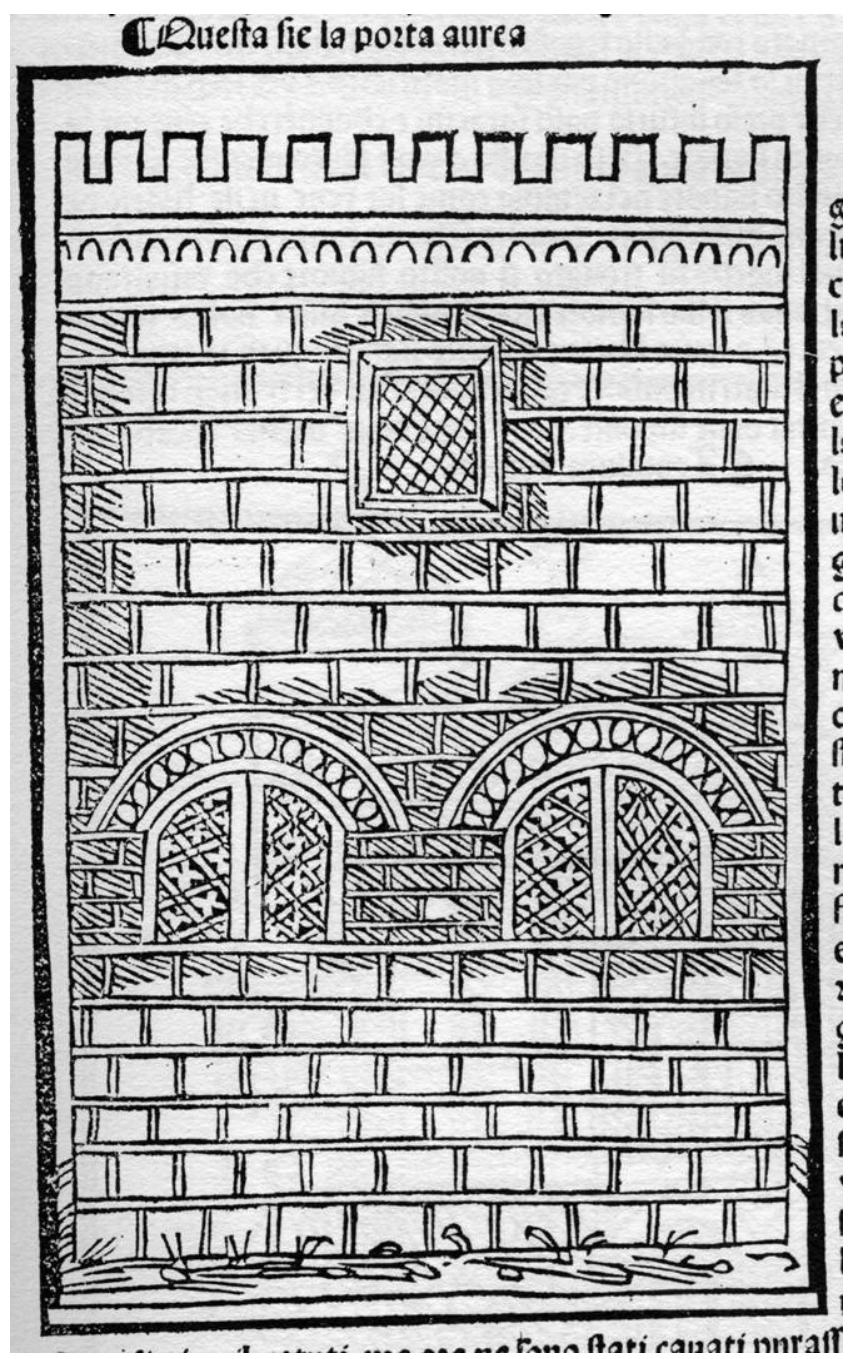

FIGURE 16. The Golden Gate, Viazo da Venesia al Sancto Iherusalem. Bologna, 1500. Image from Viazo da Venesia al Sancto Iherusalem (Rome: Edizioni dell'Elefante, 1972).

the illustrator of the 1500 Viazo, Piero Ciza, is known, no such name is found in the 1518 edition and none of the woodcuts have signatures. ${ }^{76}$ The design of the 1518 edition has never been attributed to a known

${ }^{76}$ Essling, 1907, 354. 


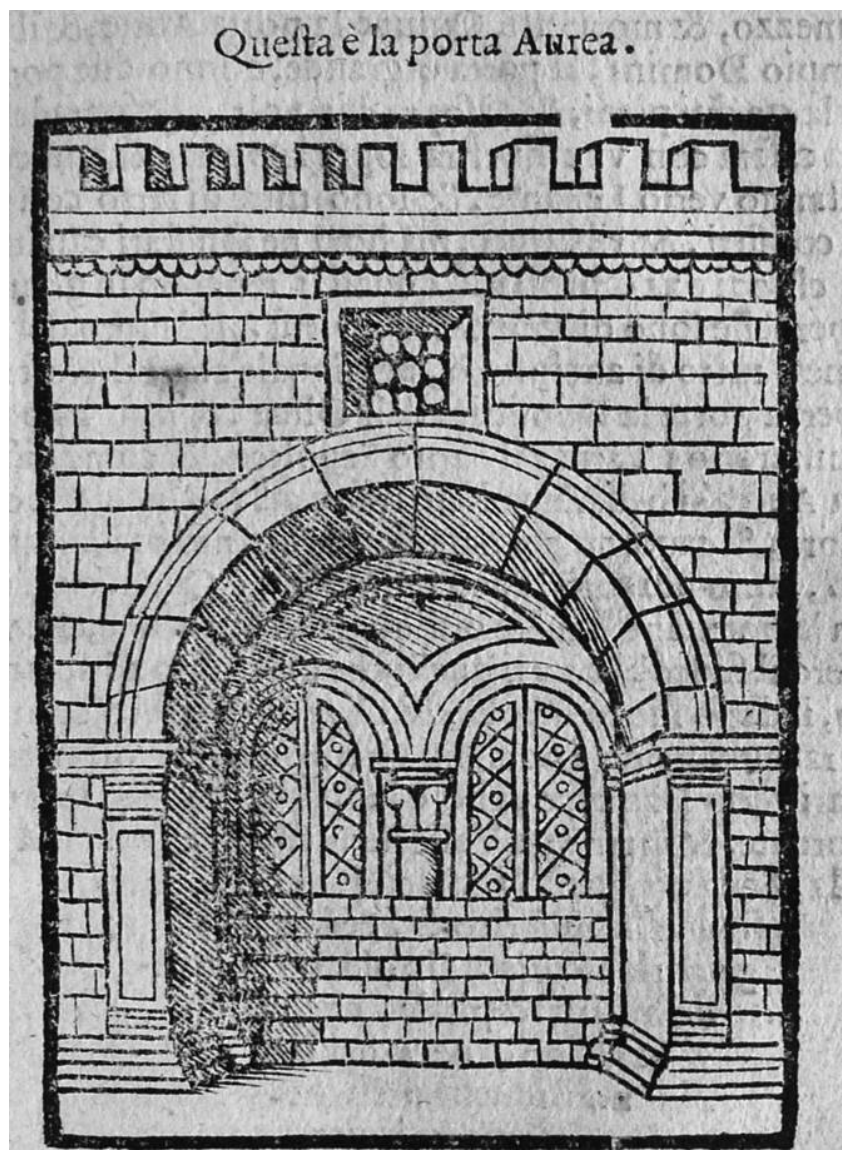

FIGURE 17. Golden Gate, Viaggio da Venetia al Santo Sepolcro et al Monte Sinai. Venice, 1606. Research Library, Getty Research Institute, Los Angeles (88-B1091).

artist. $^{77}$ Whoever the designer of the 1518 Viaggio may have been, it is only in the third edition of the book, produced in 1520 by a new publisher, Joanne Tacuino, that a signature appears in one of the woodcuts. The

${ }^{77}$ It is tempting to suggest that Benedetto Bordone may have been the designer who created the woodcuts of the Viaggio da Venetia inspired by the Bolognese Viazo. The woodcut illustrations for Bordone's Isolario, first published as the Libro di Benedetto Bordone for Niccolò detto Zoppino in 1528 - the same publisher of the 1518 Viaggio — show a similar transformation of previous woodcut illustrations. The bold simplification of Jacopo de' Barbari's enormous and complex 1500 woodcut illustrating Venice in the 1528 Libro di Benedetto Bordone is similar to the reduction of Reuwich's large panoramas of Jerusalem and Corfu in the 1518 Viaggio: see Bordone and Skelton. 


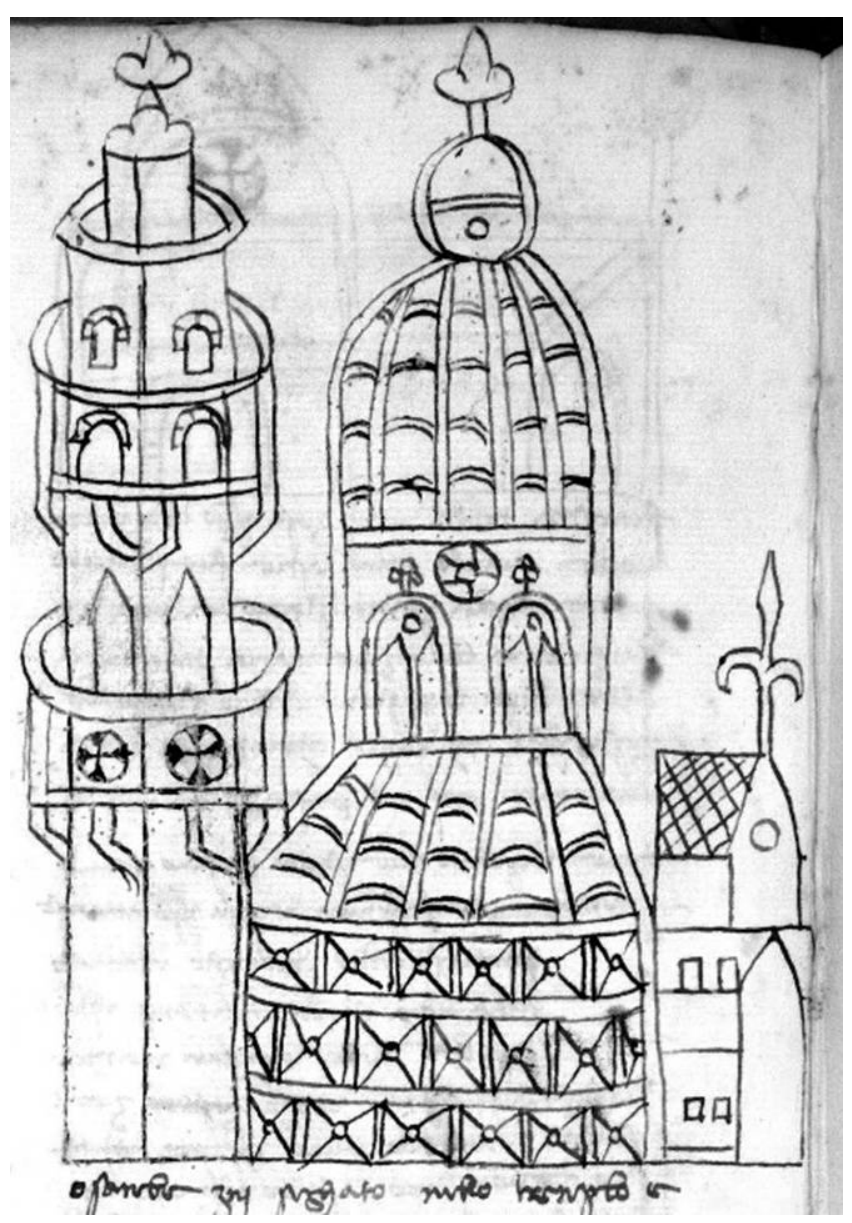

FIGURE 18. Templum Salamonis Templum Domini, BNCF II. IV. 101, fol. $20^{\mathrm{v}}$. Biblioteca Nazionale, Florence. By kind permission of the Ministero per i Beni e le Attività Culturali della Repubblica Italiana / Biblioteca Nazionale Centrale di Firenze.

monogram "L" is found in the illustration of Venice, which otherwise is a reworking of the illustration in the 1518 Viaggio. $^{78}$ The source of this illustration, in fact, was not Breydenbach's Peregrinatio, but rather Fracanzano da Montalboddo's Paesi Novamente Ritrovati (Newly Discovered Countries), published in 1517 by Zorzi de Rusconi Millanese. ${ }^{79}$

${ }^{78}$ The illustration of Jerusalem in the 1520 edition is reproduced in Essling, 1907, 354; Poggibonsi, 1520.

${ }^{79}$ Essling, 1907, 387. See Montalboddo. 


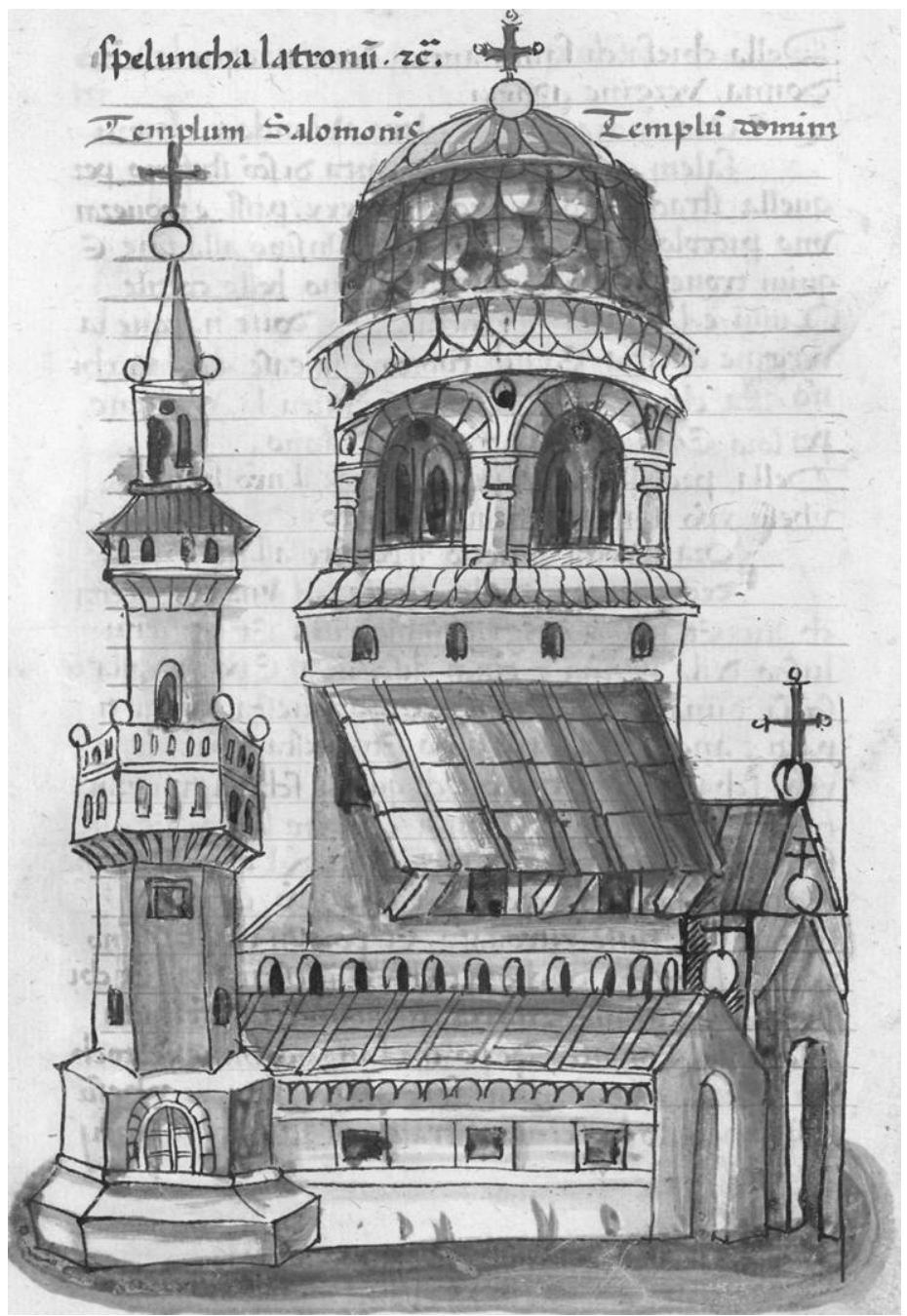

FIGURE 19. Templum Salamonis Templum Domini, NYPL Spencer 62, fol. $42^{\mathrm{r}}$. Spencer Collection, The New York Public Library; Astor, Lenox and Tilden Foundations.

The 1524 edition has a series of new figural illustrations with no precedent in the illustrated versions of Niccolò da Poggibonsi's Libro d'Oltramare. This edition was published in Venice by Nicolo Zoppino and Vicenzo de Polo with a new title: Viaggio da Venetia al santo Santo Sepulchro \& al monte Monte Synai, con disegni de Paesi Città Porthi Chiese \& Santi luoghi con additione de genti \& animali che se trouano da Venetia sino al santo 


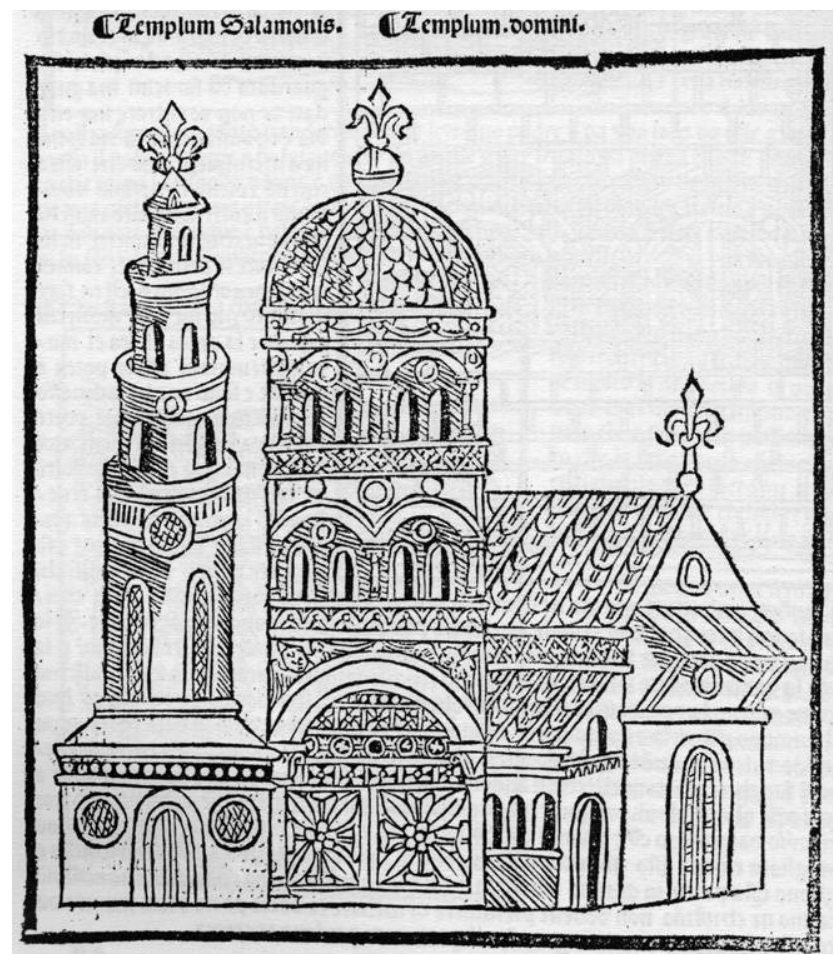

FIGURE 20. Templum Salamonis Templum Domini, Viazo da Venesia al Sancto Iherusalem. Bologna, 1500. Image from Viazo da Venesia al Sancto Iherusalem (Rome: Edizioni dell'Elefante, 1972).

Sepolchro \& per tutta la Soria: tratti dal suo naturale: non mai piùstampate (Voyage from Venice to the Holy Sepulcher \& to Mount Sinai, with Drawings of the Countries, Cities, Ports, Churches, and Holy Places with the Addition of the Men and Animals that One Finds from Venice until the Holy Sepulcher and all through Syria: Taken from Nature: Never before Published). ${ }^{80}$ These five never-before-published illustrations taken from nature of the people and animals found on the voyage from Venice each include the monogram "z.a." 81 This monogram is found on many woodcuts produced in Venice

\footnotetext{
${ }^{80}$ Essling, 1907, 357.

${ }^{81}$ The new illustrations are entitled "the Venetian gentlemen which accompany the pilgrims who go to the holiest Sepulcher, the men of Corfu depicted from nature, the men $\&$ religious [men] of Crete depicted from nature, and the great master of Rhodes with his knights, the Camel which carries loads of the Moors" (Poggibonsi, 1524). Essling, 1907, 355-57, reproduces these woodcut illustrations.
} 


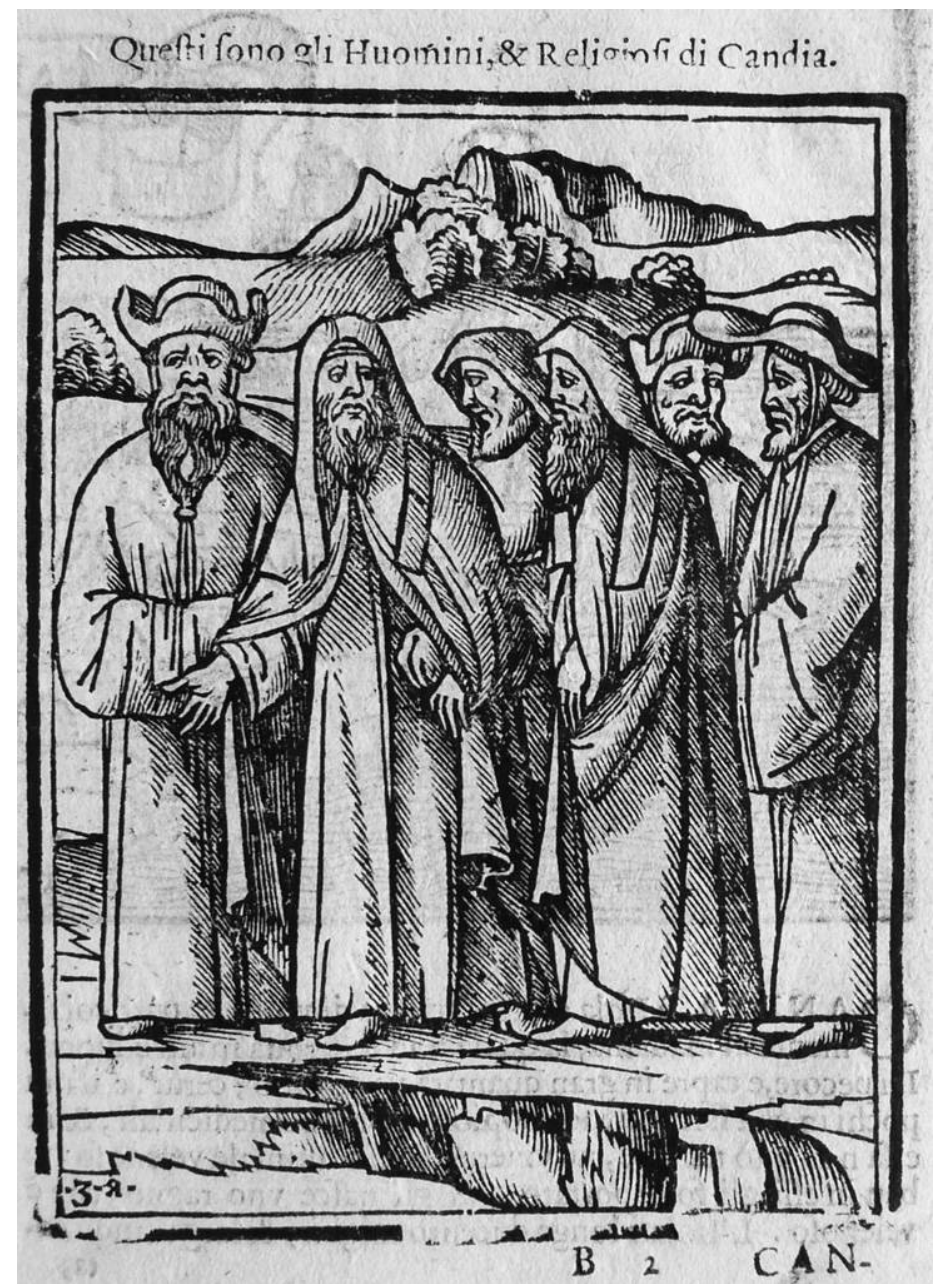

FIGURE 21. The men of Crete, Viaggio da Venetia al Santo Sepolcro et al Monte Sinai. Venice, 1606. Research Library, Getty Research Institute, Los Angeles (88-B1091).

from around 1516 onward, and whether it can be associated with Zuan Andrea, Zuan Andrea Vavassori, or another artist or artists remains controversial. ${ }^{82}$ The new figural illustrations were included in most, but not

${ }^{82}$ This controversy dates back to the late nineteenth century. See, for instance, the entry on Vavassori in Bryan, Graves, and Armonstrong, 639. Essling, 1907, 391, reproduces several other examples of Venetian woodcuts with the "z.a." monogram, for instance, in the Secreto de Francesco Petrarcha published in 1520, also by Nicolo Zoppino and Vicenzo de Polo. For a discussion of woodcuts with this monogram, see also Essling, 1892, xli-xliii. 
all, subsequent editions of the Viaggio da Venetia, sometimes without the "z.a." monogram (fig. 21). ${ }^{83}$

Surprisingly few changes were made to the content of Niccolò da Poggibonsi's Holy Land guidebook, even as it was copied in various manuscripts in the Tuscan vernacular in the fifteenth century, transcribed into the Bolognese dialect in 1500, and re-Tuscanized for the 1518 edition published in Venice. The final dedicatory letter written in Latin by Giovanni Cola for the 1500 edition was omitted from all subsequent editions, as mentioned above. At the end of the 1518 edition a new section of advice for pilgrims was added, including a remedy for lice. This is kept in later editions with an added preface, first found in 1519, of further instructions for making the pilgrimage, taken directly from Santo Brasca's guidebook. ${ }^{84}$ These amendments indicate that the Viaggio da Venetia, as it was reconceived in Venice in the beginning of the sixteenth century, was especially aimed at pilgrims in Venice about to leave on the Holy Land journey. In the 1523 edition a list of the parishes, convents, confraternities, and holy relics of Venice appears for the first time, suggesting an interest in promoting Venice, in its unique liminal position between Italy and the Holy Land, as an extension of that sacred territory. ${ }^{85}$ The increasingly long titles of the

${ }^{83}$ Poggibonsi, 1524. The 1538 edition (Poggibonsi, 1538) published by Tacuino is an example of an edition that does not include the figural illustrations first made for the 1524 edition. A copy can be found in the Spencer Collection of the New York Public Library. The "z.a." monogram is also in the 1647 (Poggibonsi, 1647) and 1690 editions (Poggibonsi, 1690). A copy of the 1647 edition can be found at the British Library, while both Columbia University in New York and the Biblioteca Nazionale Centrale in Florence have copies of the 1690 edition. The same illustrations in the 1640 edition (found at the British Library) have a "VF" monogram. The 1640 Viaggio is the only one that I have seen with such a monogram (Poggibonsi, 1640). A copy of this edition can be found at the British Library. Both the 1640 and 1647 editions are not included in the lists of known editions of the Viaggio da Venetia, as compiled by Röhricht and by Bellorini (in Poggibonsi, 1945a). Several editions include the illustrations but omit the monogram, for instance, the 1600 Treviso edition. Slight modifications or additions to the woodcuts continue to be made throughout the later editions. For instance, the 1800 edition adds an illustration of a synagogue in one of the last sections on the orations of Jews (Poggibonsi, 1800). The British Library possesses a copy of this final edition of the Viaggio da Venetia.

${ }^{84}$ Similar instructions for pilgrims are also found in the account of Giovanni Capodilista's journey of 1458, Itinerario in Terra Santa (Journey into the Holy Land): see Nardone and Malherbe-Galy, 36, 45.

${ }^{85}$ See Essling, 1907, 128. By the beginning of the seventeenth century many editions were also published with a new table denoting the distance between places on the journey. This table was taken from Noe Bianco's guidebook (1566): see Nardone and Malherbe-Galy, 34. 
seventeenth- and eighteenth-century editions reflect the accretive nature of the guidebook. ${ }^{86}$

Despite the various additions to the Viaggio da Venetia over the course of three centuries, vestiges of Niccolò da Poggibonsi have remained in the text. In each of the over sixty editions, published from 1500 to 1800 , the description of the author has remained in the very first pages, and the story is still told from the perspective of this first-person narrator. ${ }^{87}$ The idea of a pilgrim who originally created the entire book — both its text and illustrations — during his journey through the Holy Land was maintained even though his name was omitted. ${ }^{88}$ The omission of the author's name in the first edition of 1500 did not necessarily amount to intentional plagiarism, but could have resulted from the repeated copying of the original fourteenth-century guidebook in manuscript form. The addition of the description of the pilgrim-author to the 1500 text filled the gap left by the absence of an author name, even as it asked for its eventual return.

\section{THE FRANCISCAN CONTEXT}

It is likely that by the beginning of the seventeenth century the connections of the guidebook to the Tuscan manuscripts of the fourteenth- and fifteenthcentury were unknown to the Venetian publishers of the Viaggio da Venetia. With the publication of a Holy Land guidebook in the sixteenth century by another holy man, Fra Noe Bianco of the Servite order, the seventeenthcentury editors were presented with the possibility of implying the identity of the author. The book had become a bestseller by this point, and the reverend (albeit fictional) name of the Franciscan Fra Noe undoubtedly

${ }^{86}$ See, for example, the 1640 edition: Viaggio da Venetia al S. Sepolcro et al Monte Sinai col dissegno delle città, castelli, ville, chiese, monasterij, isole, porti, \& fiumi, che sin la si ritrovano, Et una breve regola di quanto si deve osservare nel detto viaggio, e quello, che si pagha da luoco à luoco si di datij, come d'altro cose. Composto dal R. Padre Fra Noe dell'ordine di San Francesco. Aggiuntovi il modo di pigliar le sante indulgenze \& à che chiese, monasterij, \& altri luoghi siano concesse. Di nuovo aggiuntovi una tavola, che dinota quanto miglia sono da luoco infino a Gierusalemme (Voyage from Venice to the Holy Sepulcher and to Mount Sinai with the Drawing[s] of the Cities, Castles, Towns, Churches, Monasteries, Islands, Ports, and Rivers, that One Finds There, and a Brief Rule of How Much One Must Observe in the Said Voyage, and that which One Pays from Place to Place Is Given, as [Are] Other Things. Composed by the Reverend Fra Noe of the order of Saint Francis. With the Addition of How to Receive Indulgences, and to What Churches, Monasteries, and Other Places They Are Granted. With the New Addition of a Table, which Denotes How Many Miles There Are from Place [to Place] until Jerusalem).

${ }^{87}$ See Appendix 2.

${ }^{88}$ See Appendix 1. 
enhanced the authority of the book's explication of the system of indulgences connected to Holy Land pilgrimage. Even given the possible intention of implying a connection to the Servite Noe Bianco, the later editions of the Viaggio da Venetia, beginning in 1600, consistently refer to the author as Fra Noe of the Franciscan order (R. Padre F. Noe dell'ordine di S. Francesco). This may relate to the continuing importance of the Franciscans, both as the original institutors of the system of indulgences in the Holy Land and as the official custodians of pilgrimage sites: their role as the Custodia Terrae Sanctae (Custody of the Holy Land) was formalized in $1342 .{ }^{89}$ The Franciscans played a central role in changing the perception of the Holy Land in the early modern period, especially by promoting the perception of the architecture of Jerusalem, Bethlehem, and Nazareth as redolent with redemptive power, quantified through the new system of indulgences that they both generated and codified. Indeed, the oldest manuscript versions of the Libro d'Oltramare, based upon the Franciscan Fra Niccolò da Poggibonsi's pilgrimage of 1346-50, contain the most comprehensive verbal and pictorial survey of the pilgrimage sanctuaries, in addition to the earliest account of the expanded system of indulgences. ${ }^{90}$

The Franciscan context for Fra Niccolò's Libro d'Oltramare, as well as the many printed editions of the Viaggio da Venetia based upon it, suggests that these illustrated books belong to a larger category of virtual pilgrimages promoted by the Franciscan order, intended to allow those who could not travel to Jerusalem to experience the Holy Land. ${ }^{91}$ These Franciscan projects were characterized, first, by a unique familiarity with the architectural landscape of the life of Christ, as a result of the Franciscan custody of the Holy Land, and, second, by an innovative use of a variety of media in concert - reflecting a "multimedia mentality," as Jeffrey Hamburger puts it - to help facilitate the contemplative engagement with the life of Christ. ${ }^{92}$ The text of the Libro d'Oltramare, for example, emphasizes the sensory experience of the pilgrimage sanctuaries through detailed descriptions of movement through architectural spaces, measurements, and materials, altogether facilitating an embodied experience of the architectural relics of the life of Christ. ${ }^{93}$ This vicarious experience was augmented by the simple architectural drawings that inspired the woodcuts of the Viaggio da Venetia.

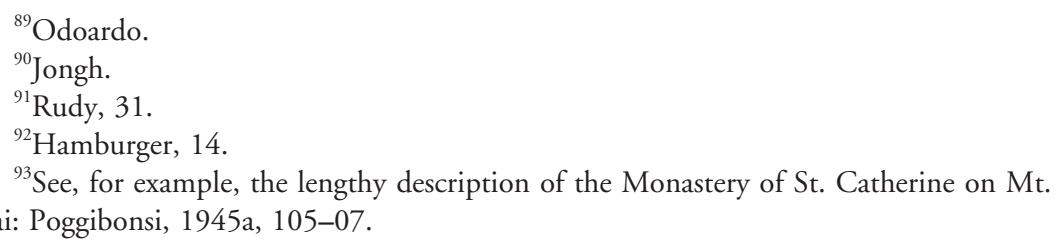


The idea of creating pictorial illustrations during the journey, as Niccolò da Poggibonsi did, was in itself a significant departure from previous approaches to creating pilgrimage accounts. The text of the Viaggio da Venetia, even if it never gives the Franciscan friar's name, retains the memory of the eyewitness experience of the original author as the creator of the book. ${ }^{94}$

Franciscans developed other forms of proxy pilgrimages beyond the context of illustrated books. A similar approach to the idea of virtual pilgrimage is evident in the famous murals of the Basilica of San Francesco in Assisi, founded in 1226, of which Fra Niccolò was undoubtedly aware. The attention to architectural detail and emotional vividness in the mural paintings have been broadly categorized as part of "Franciscan realism." The basilica itself has been interpreted as a recreation of the Church of the Holy Sepulcher in Jerusalem, heightening the effect of the spectator's engagement with the life of Christ, as imagined in the many frescoes within. ${ }^{96}$ At the Sacro Monte of Varallo, founded in 1491 as the first of a series of sacred mountains, the Franciscan Fra Bernardino Caimi (ca. 1425-1500) instituted a more literal vision of virtual pilgrimage. On the small hilltop site near Milan, a series of chapels were constructed that served as the setting for sculptural arrangements, reconstituting in real space scenes like the Lamentation and Nativity depicted in Assisi, replete with real hair, clothes, and moveable limbs. ${ }^{97}$ Fra Bernardino, like Fra Niccolò, was ultimately participating in the same innovative spirit of experiential piety promoted by St. Francis and the order that he founded in 1209. ${ }^{98}$ Most famously, Francis had instituted what was considered to be the first Nativity scene at Greccio just three years before his death in 1226. ${ }^{99}$ This idea was expanded at Varallo, where, in addition to the Chapel of the Nativity in Bethlehem, every major pilgrimage site in the Holy Land was recreated on the hilltop site. ${ }^{100}$ The creation of the Sacro Monte of Varallo postdates the origins of the Libro d'Oltramare, but its immense popularity in the sixteenth and seventeenth centuries parallels the success of the anonymous printed version of Fra Niccolò's book, which in a

\footnotetext{
${ }^{94}$ See Appendix 1.

${ }^{95}$ Rosenthal.

${ }^{96}$ Cooke.

${ }^{97}$ Wharton, 97-105; see also Hood.

${ }^{98}$ Flora, $18-20$. For a more general overview of the features typical of Franciscan vernacular literature, see Jeffrey.

${ }^{99}$ On history of the Nativity scene created at Greccio, and its relation to re-creations of the Chapel of the Nativity in Bethlehem both at the Sacro Monte of Varallo and the church of Santa Maria Maggiore in Rome, see Ostrow, 18, 39-42.

${ }^{100}$ Leatherbarrow.
} 
different fashion allowed the reader to experience the Holy Land without leaving Italy.

Two-and-a-half centuries after Fra Niccolò's journey, another Franciscan friar produced a new survey of the major pilgrimage sanctuaries of Jerusalem, Bethlehem, and Nazareth. Fra Bernardino Amico (fl. 1593-1619), who created both the text and illustrations of his treatise, entitled the Trattato delle Piante \& Imagini dei Sacri Edificii di Terra Santa (Treatise of the Plans and Images of the Scared Edifices of the Holy Land), was motivated by a similar interest in helping Italians vividly imagine these buildings. ${ }^{101}$ The sophisticated perspectival views are, as Fra Amico states, to allow the viewer to look at buildings like the Church of the Nativity in Bethlehem as if they are three-dimensional models emerging from the page. ${ }^{102}$ In many ways Amico's Trattato is a genealogical descendent of the illustrated versions of the Libro d'Oltramare, pairing textual descriptions and visual representations in a comprehensive survey of the churches of the Holy Land, but drawing on the developments in architectural representation in the intervening years. In contrast to the persistent popular appeal of the Viaggio da Venetia, the success of Amico's Trattato seems to have been limited, having been published in only two editions, first in Rome in 1609, then in Florence in 1620. What is lacking in Amico's meticulous architectural drawings and careful descriptions of the churches of Jerusalem, Bethlehem, and Nazareth is that which remains in Niccolò's account even as his name became separated from the text: the sense of adventure in the story of a pilgrim's journey, and the sense that the buildings of the Holy Land both retain the traces of Christ's charisma and promise of the remission of sin. By the seventeenth century, the continual reprinting of the book with little modification and no mention of the Ottomans or the need for a new crusade to retake the Holy Land (as in Amico's Trattato) could have also been perceived as comforting evidence of the unchanging spiritual potency of the Christian holy sites.

\section{CONCLUSION}

At the time of the creation of the Libro d'Oltramare in the mid-fourteenth century, the adoption of the vernacular as well as the dominating first-person narrative voice were just as significant authorial choices as the addition of a comprehensive series of pictorial illustrations. Both choices link the book

\footnotetext{
${ }^{101}$ Amico, 1609. For the English translation and reproduction of the architectural illustrations, see Amico, 1953.

${ }^{102}$ Amico, 1953, 48.
} 
to the works of Niccolò da Poggibonsi's famous contemporaries: Dante Alighieri (1265-1321), Francesco Petrarca (1304-74), and Giovanni Boccaccio (1313-75). By choosing to write in the vernacular, and by not deferring to the authority of previous Latin texts, Niccolò da Poggibonsi can likewise be considered a protomodern author, motivated by the same dynamic creativity and assertive individualism that Albert Ascoli has identified in the works of Dante. ${ }^{103}$ Indeed, like other texts of the fourteenth and fifteenth centuries that have been associated with the emergence of the modern author, the Libro d'Oltramare is not a synthetic composition or memorial recollection of fragments from previous texts: instead, it is a first-person eyewitness account, an "I"-centered work. ${ }^{104}$ Niccolò approached the idea of creating a personal travelogue transformatively, selfconscious of the novelty of his enterprise, emphasizing his personal experiences, and describing the physical reality of the Holy Land in unprecedented detail.

It is important to emphasize, however, that Fra Niccolò would not have viewed himself as an auctor of the stature of Dante. Nonetheless, the forceful individuality of his project parallels the innovative spirit of the first vernacular literature. ${ }^{105}$ The genre of pilgrimage accounts, which had no ancient texts as their basis, as a whole lacked auctoritas. ${ }^{106}$ Although elements of Dante's Commedia, in particular the Purgatorio, were apparently

${ }^{103}$ Ascoli, 9-12.

${ }^{104} \mathrm{Ibid}$., 36-37. See also Carruthers, 194, 214-15. A good example of the more typical, synthetic composition of previous texts, is Bede's, largely taken from Arculfs eyewitness account: "I, Bede, have briefly described the boundaries and the sites of those places of which the Holy Page speaks as specially worth remembering. I have followed the writings of the ancients and at the same time examined what is written on the parchments of more recent masters": Wilkinson, 216. Niccolò only once directly refers to a previous author, although not by name. This is in his reference to the legend of the Holy Cross: "As one doctor says the cross of Christ was of four woods; for the upright of the cross was the wood which Seth the son of Adam, our father, brought from paradise": Poggibonsi, 1945a, 57. He is referring to St. Bonaventure's Vitis mystica: see Bonaventure.

${ }^{105}$ Quint, 1, argues that the "new personal voice" of the author was invented by Renaissance humanism, positing a sharp break between the medieval and Renaissance eras. Before that, Spitzer denied that the "I" in medieval texts related to any true creative identity, arguing that the speaking "I" was generic and ultimately subsumed under the authority of divine creativity: see Spitzer. Ascoli provides a more nuanced argument regarding the relation of medieval and Renaissance notions of authorship.

${ }^{106}$ Campbell has described travel literature as a genre composed of other genres, which nonetheless contributed to the formation of the modern novel and autobiography. Campbell argues that Egeria's pilgrimage account is the first example of European travel literature, because for the first time "pilgrimage renders the journey important as journey": Campbell, 6-7, 15-16. 
patterned on descriptions of the pilgrimage to the Holy Land, Dante did not draw attention to these sources - in contrast to his self-conscious engagement with the authority of Virgil's Aeneid, for example. ${ }^{107}$ Despite these qualifications, Niccolò da Poggibonsi was an integral part of the "evolving construction of authorship at the dawn of a properly European and vernacular culture." ${ }^{108}$ From the perspective of modern scholars, however, the lack of an author's name has deprived the Viaggio da Venetia of any real historical significance. Rejoining the Viaggio with the historical figure of Niccolò da Poggibonsi expands an understanding of a transgenerational discourse across the media of manuscript and print, and reframes the book in its initial context at the moment of the genesis of the modern author.

The tenacity of Fra Niccolò as author, despite the erasure of his name, especially in the recurring presence of the speaking "I," is remarkable. The unnamed friar remains the generator of the book, as the pilgrim whose desire to see and touch everything with his own eyes and hands taps into a pervasive volition on the part of Italians, who similarly wished to encounter the relics of the life of Christ in lieu of his absent body, if only vicariously. The attribution of the seventeenth-century editions to the fictive Fra Noe reflects an understanding of the unique role of the Franciscans as authorities regarding the pilgrimage experience. Even with this fictive attribution, the author of the Viaggio da Venetia retains a universalized, transcendental status that unites the various editions published over three centuries. Indeed, rather than asserting that Niccolò da Poggibonsi be returned to the Viaggio da Venetia as its author, his role as the inceptor of a new genre might be asserted: the illustrated Holy Land guidebook, written in the vernacular and in the first person, of which the Viaggio da Venetia is an integral part. ${ }^{109}$ Niccolò's guidebook was inaugural in that it established the modes and possibilities for a series of texts that followed it, in particular, Gabriel Muffel's (d. 1498) guidebook (BL Egerton 1900), the anonymous Viaggio of NYPL Spencer 62, Breydenbach's Peregrinatio, the 1500 Viazo, Amico's Trattato, and many other related guidebooks. Breydenbach may have found in an illustrated copy of Niccolò da Poggibonsi's guidebook his inspiration for bringing an artist to illustrate his journey with depictions of the buildings, cities, and animals of the Holy Land. The conceptual similarities of both guidebooks allowed for the modern presumption that the Viaggio da Venetia was a debased version of the Peregrinatio. Rather than viewing the 1500 Viazo and the sixteenth-century editions of the Viaggio da Venetia as derivative in

\footnotetext{
${ }^{107}$ See Demaray. For Dante's relation to the authority of Virgil, see Ascoli, 20-21.

${ }^{108}$ Ascoli, 25 (referring here to Dante).

${ }^{109}$ Foucault, 123. See also Burke, 93.
} 
relation to the 1486 Peregrinatio, all of these might be seen instead as part of a larger discursive formation whose origins were in the fourteenth century, and whose author - in the broadest sense — was Niccolò da Poggibonsi.

University of California, Berkeley, ACLS NeW FACULTY FELLOW 


\section{Appendix 1: Preface*}

The following passage from two manuscript and two printed versions shows how the author's name was omitted in the later versions, and compares the different dialects employed in each. Both BNCF II. IV. 101 and NYPL Spencer 62 employ the Tuscan dialect, albeit one of the fourteenth and one of the fifteenth century, while the 1500 Viazo employs a Bolognese dialect, which was then re-Tuscanized for the 1518 Viaggio.

\section{BNCF II. IV. 101, fol. $1^{\mathrm{r}}$}

In the name of God, and of his mother the sweet Virgin Madonna Saint Mary, and of the blessed Father Saint Francis, and of the blessed doctor Saint Augustine, and of Saint Bartolomeo gracious apostle and of Saint ... and of Saint Nicholas ... and of Saint Catherine beloved wife of ... crucified Christ, and of all the saints of paradise that give their grace so that I might say and write in order, and recount the holy places of overseas without failing, as I visited them. And in order to see all these things I spent more time there than four years. And who here will read will find all the indulgences in order, and the spaces, and the sizes of the holy places, and also the things that are inside, and how they are ordered, and the routes that are in the Holy Land, but of others I will not write; but I will say a little of the sanctuaries of Venice, and then we will pass beyond into the Holy Land; how one goes in the whole kingdom of the Sultan of Babylon of the land of Egypt, lord of the Saracens of the Holy Land, and of Syria, and of Arabia, and part of Ethiopia, and of many crowned kings. Also I will write that which one pays in tribute going through his kingdom, and however the name of this book might be the book of beyond the sea, and from now on I will begin to write; but in order that nothing of my corporal effort be lost and that no person might claim for himself this said work, that I have made for the said book; and that no one might say to have made [this book] other than I brother Nicholaio of the Frati Minori of Saint Francis from Poggibonsi; and who would want to find my name and that of my father will find my name by reading beginning from this point forward the first capital letter of the chapter, and read until the big $\mathrm{F}$ and there begins my other name, and then you will find the other name of my father.

Al nome di Dio e della sua madre dolce Vergine Madonna Santa Marea, e del beato Padre Santo Francescho e del dottore beato Santo Aghostano e di Santo Bartolomeo apostolo grazioso e di Santo ... e di Santo Nicholo ... dimora chosì e di Santa

"I have added accent marks and apostrophes to indicate contractions, but otherwise have not modified the texts found in these transcriptions. This first paragraph in BNCF II. IV. 101 forms the preface, and the following chapter, in which Niccolò recounts how he left from Poggibonsi in 1346, traveling via Florence, Bologna, Ferrara, and Chioggia to Venice in order to set sail in April of 1346, is omitted from NYPL Spencer 62, the 1500 Viazo, and the 1518 Viaggio. The chapter is copied in BNCF Panc. 78 and presumably would have been included in BNCF Panc. 79 as well, although the first folios of the latter manuscript are missing. 
Chaterina deletta sposa di ... Cristo crocifisso e di tutti santi e sante di paradiso che ci doni la sua grazia si ch'io possa dire e scrivere per ordine e chontare le sante luoghora d'oltra mare senza fallimento, sì chom'io le visitai. E per vedere tutte queste chose io ci spesi di tempo più di quattro anni. E chi qui legerà troverrà tutte le indulgenzie per ordine, e gli spazii, e grandezze delle sante luoghora, e anche quelle che vi sono dentro, e chome sono ordinate; e le vie cioè quelle che sono in Terra Santa che dell'altre non ne scrivo; ma dirò un pocho de santuarij di Vinegia e poi passeremo oltre in Terra Santa; chome si va in tutto l'imperio del Soldano di Bambillonia di terra d'Egitto, signore di Saracini e di Terra Santa, e di Soria, e d'Arabia, e parte di Etiopia, e di molti re inchoronati. E chosì scrivverò ciò che si pagha di trebuto andando per suo imperio, e però lo nome di questo libro sia chiamato libro d'oltre mare e anchora innanzi inchomincerò a scrivere ma acciò che la mia faticha chorporale niente sia perduta che nulla persona lo detto travaglio, che io ebi [ebbi] per lo detto libro asse [a se] nollo riputi, ne che possa dire che l'abi [l'abbia] fatto altro che io frato Nicholaio de Frati Minori di Santo Francescho da Poggibonizi, e chi il mio nome e di mio padre vorrà trovare la prima lettera miniata del capitolo che da ora innanzi si comincia legendo lettera per lettera mio nome troverrà, e leggi infini a lo grande $\mathrm{F}$ e ivi si comincia l'altro mio nome, e allora troverrai il nome di mio padre.

\section{NYPL Spencer 62, fol. $1^{\mathrm{r}}$}

Now begins the voyage of the Holy Land of Jerusalem, telling of all the cities, lands, and holy churches, which one finds going and returning through sea and through land, drawing the places as they are situated and those things that one finds there. And contained in these are all of the indulgences that there are in all the glorious and holy places which today are visited by those who go on pilgrimage; and what you must [do] in all those places where the sign of the Holy Cross is and full absolution of pain and of guilt; but in the other places where the sign of the Cross is there is indulgence of seven years and of forty days; and the said indulgences by Pope Saint Sylvester and by prayers of Saint and great Emperor Constantine and of his mother Saint Helen. Now I will begin the said voyage or rather pilgrimage of the most powerful city of Venice, telling of its appearances, and so we will tell of each place as one goes and returns, drawing every place as best one might. And we will tell thus in the name of Jesus Christ.

In commincia in ogni modo il viaggio della terra sancta di Yherusaleme, narrando nominatamente di tutte le città, terre, e sancti chiessi, i quali si trovano all'andare et al tornare per mare et per terra, figurando le luogho sie como situati e quelle cosse che vissi trovano. Et contienuissi in questi tutte le indulgentie chessono in tutte le gloriose e sante luogora i quali al dì d'oggi sono visitati di chi va in pellegrinaggio; E dovete che in tutte quelle luoghora dove il segno della sancta Croce quivi e piena absolutione di pena e di colpa; Ma nell'altre luogora dove non e il segno della Croce sie indulgentia di Sette anni e di quaranta dì. Elle predicte indulgentie da Santo Silvestro papa a prieghieri del santo e magno Imperadore Constantino e di Santa Helena sua madre. Ora pigliero il predicto viaggio overo pellegrinaggio dalla 
potentissima città di Vinegia dicendo delle sue fatezze e cosìdiremo di luogo in luogho dell'andare e del tornare figurando ogni logo come meglio si potra. E diremo cosìnel nome di Yhesu Christo.

1500 Viazo da Venesia al Sancto Iherusalem (Petrucci and Petrucci, 1)

Voyage from Venice to holy Jerusalem and to mount Sinai, sepulcher of Saint Catherine, more copiously and truthfully described, than any of the others, with drawings of countries, cities, ports, and churches and holy places and many other sacred things that here one finds drawn and described as they are in their places, et cetera. Jesus son of God miserere mei qui crimina tollis. Now let be with us the power of God, the father, and the wisdom of God the son, and the virtue of the Holy Spirit, most blessed Trinity. Amen. This voyage of the holiest Sepulcher of our lord Jesus Christ a worthy man wrote, who wanted to go with the help and willingness of the omnipotent God. And deliberately leaving from Venice, he wanted to write and at the same time draw all of the lands, ports, cities, [and] villages, from one place to the next through sea and through land. And at the same time he was drawing the churches and holy places that he found through all of his journey, with their indulgences and the remissions of places where conversed our lord Jesus Christ and his sweetest, glorious Virgin Mary and his holiest Apostles and holy disciples and other saints; and first and primarily [this] tells of the most worthy city of Venice and of its adornments, and how they are built and situtated, and of the memorible things which are there, thus telling.

Viazo da Venesia al sancto Iherusalem et al monte Sinai sepulcro de sancta Chaterina più copiosamente et verissimamente descrito, che nesuno de li altri, cum dessegni de paesi, citade, porti, et chiese, et sancti luoghi et molte altre sanctimonie que qui se trovano designate et descrite chome sono neli logi lor propri, et cetera. Ihesu filii Dei miserere mei qui crimina tollis. Ora sia chon noi la potentia di Dio padre e lla sapientia di Dio figliolo e lla virtù dello Spirito sancto, beatissima Trinitade. Amen. Questo infrascrito viaggio del Sanctissimo Sepolchro del nostro signore Ihersu Christo il scrisse un valente huomo, il quale si dispuose di volervi andar coll'aiuto et volere de lo omnipotente Dio et diliberatamente partendosi da Vinegia, volle scrivere et etiamdio disegnare tutte le terre, porti, cittade, vilaggi, quante da l'uno logho all'altro per mare et per terra, et etiamdio figurava le chiese et i sancti loghi che vi ssi trovano per tutto quello viaggio, colle loro indulgentie e remissione di loghi dove conversava il nostro signore Ihesu Christo e lla sua dolcissima, gloriosa vergine Maria e lli soi sanctissimi apostoli et sancti discipoli et altri sancti et sancte; et prima e principalmente dice della dignissima città de Vinegia et delle sue adorneze, et come sono edifichate et situate, et delle memorabile cosse che vi sono, dicendo così.

1518 Viaggio da Venetia al Sancto Sepulchro (Poggibonsi, 1518, n.p.)

Voyage from Venice to the Holy Sepulcher and to Mount Sinai more copiously described than the others with drawings of countries, cities, ports, and churches, and the holy places with many other sacred things that here one finds drawn and described as they are in their own places. Jesus Christ son of God miserere mei qui 
crimina tollis. Now have with us the power of God the father, and the wisdom of God the son, and the virtue of the Holy Spirit most blessed Trinitiy. Amen. This here written voyage of the holiest Sepulcher and of our lord Jesus Christ a worthy many wrote: he who was disposed to want to go with the help and will of the allpowerful God; and deliberately leaving from Venice he wainted to write, and at the same time to draw all the lands, ports, cities, and villages; how many [miles] from one place to another through sea and through land. And at the same time he was drawing the churches and the holy places that there one finds for all of that journey with their indulgences and remissions of the places where conversed our lord Jesus Christ and his most sweet glorious Virgin Mary, and his most holy apostles and holy disciples, and other saints. And first and primarily [this] tells of the most worthy city of Venice and of its adornments. And how they are built and situated. And of the memorable things which are there, thus telling.

Viaggio da Venetia al Santo Sepulchro e al monte Synai più copiosamente descritto de li altri con desegni de paesi: citade: porti: e chiesie e li santi loghi con molte altre santimonie che qui si trovano designate e descritte come sono nelli luoghi lor proprij. Jesu filii Dei miserere mei. Qui crimina tollis. Ora ha con noi la potentia di Dio padre: e la sapientia di dio figliolo e la virtù de lo spirito santo Beatissima Trinitade. Amen. Questo infrascritto viaggio del santissimo Sepulchro e del nostro Signore Jesu Christo il scrisse uno valente homo: il quale se dispose di volervi andare con l'aiuto e volere de lo Onnipotente Dio. Et deliberatamente partendosi da Venetia volse scrivere. Et etiamdio disegnare tutte le terre: Porti: Citade e Vilaggio. Quante da l'uno luoco a l'altro per mare e per terra. Et etiamdio figurava le chiese e li santi luochi che vi si trovano per tutto quello viaggio con le loro Indulgentie e Remissione di luochi dove conversava il nostro signore Jesu Christo e la sua dolcissima gloriosa Vergine Maria: e li suoi Santissimi Apostoli e Santi discipoli: altri Santi et Sante. Et prima e principalmente dice della dignissima Città di Venetia e delle sue adornezze. Et come sono edificate e situate: e delle memorabile cose che vi sono: dicendo così. 


\section{Appendix 2: Introduction to the Description of the Church of the Holy Sepulcher}

The following passage from two manuscripts and two printed versions shows how the author's name was omitted in the later versions, while the content of the text still ultimately derives from the original manuscript source.

\section{BNCF II. IV. 101, fol. $6^{\mathrm{r}}$}

Now man should be wise and discreet in foresight, and to be well aware to retain his memory: and in order to not fail I will write at once of the places overseas, but I, brother Nicholaio from Poggibonsi, when I passed overseas, my mind decided to want to visit all things, and never to want to return in my country in another way. And that which with my eyes I saw, and with my hands I touched, and still other things about which I asked, and when I was certain of the thing, [then] I wrote it on a pair of tablets, which I carried by my side. Then, being in Jerusalem I took a measure of [an] arm, [and also] with a foot going, and all in order I measured the spaces in this way, as here you hear, also the lengths and the widths, and I measured all things; and then immediately I wrote [them down]. And the reason I tired myself [doing] this, is this: first that there are many who have a great wish to visit the holy places, to many [of these] poverty harms, and others give it up because of too much fatigue, and who [give it up] because of not having the permission that one must have from the pope. But from now on I will begin with the holy places of Jerusalem. But in order that my corporal effort no person might claim for himself this said work, which I have made for this said book; and that no one might say to have made [this book] other than I, brother Nicholaio; and who would want to find my name, and also the name of my father Chorbizo, and from where I was, and the first letter of the chapter that begins from this point forward, reading letter for letter, will find everything in order, as also I say following beyond. And first we will tell of the holy church of Jerusalem, and of the holy indulgences that are outside, and so we will go in order.

Ora chonverrebe molto l'uomo essere savio e discreto in providenzia, e essere bene achorto a ritenere alla sua memoria, e per non fallare scrivero tosto delle luoghora d'oltre mare, ma io, frate Nicholaio da Pogibonizi, quando passai oltre mare, l'animo mio posi di volere tutte chose visitare, e innaltro [in altro] modo mai non volere ritornare in mio paese. E quello che cho'gli occhi vedevo, e cho'le mani tocchavo, e anchora altri domandando, e chom'io ero della chosa certifichato, e io lo scrivevo in su uno paio di tavolelle che allato portavo. Poi, essendo in Ierusalem, pigliai una misura di braccio, chon uno passo andando, e tutto per ordine, chome qui udirete, sì misurava li spazi, e le lunghezze e le larghezze e arechavo le tutte a misura; e poi subito lo scrivevo. E la ragione perché di questo m'afatichavo si è questa: prima che molti che ànno grande volontà delle sante luoghora visitare, a molti nuoce la povertà, e altri lasciano per troppa faticha, e chi per non potere avere licenzia che si debia [debba] avere dal Papa. Ma da ora innanzi chomincerò a le sante luoghora di Ierusalem. Ma acciò che la mia faticha chorporale nulla persona lo detto travaglio, ch'io ebo avuto per lo detto libro, asse [a sè] nollo riputi ne che dicha l'abbi [abbia] fatto altro che io, frate 
Nicholaio, e che'l mio nome vorrà trovare, e anche lo nome di mio padre Chorbizo, e donde io fui, e la prima lettera del chapitolo che da ora inanzi sì chome si comincia, legendo lettera per lettera, tutto lo troverrà e ordinato, chome anche dicho seghitando [seguitando] oltre. E prima diremo della santa chiesa Ierosolimitana, e de sante perdonanze che sono di fuori, e chosì anderemo ordinatamente.

\section{NYPL Spencer 62, fol. $10^{\mathrm{r}}$}

Now I needed sense and foresight and [a] good memory in order that I could write in order all the holy places which there are overseas. So when I went I was disposed in my mind to never return to my country without first having informed myself entirely of all these things and places, thinking to attentively use the five senses of the body, that is, wanting to taste, smell, hear, see, and touch; and to ask and seek out the truth and to measure by steps for length and for width; and then to write everything and to draw together as I could; however, that often there are those who willingly would visit and search out these holy places; and who can not for poverty, [while] some do not do it for fatigue or for tedium; and also who can not have that which one must have from the pope. And so I intend to recount briefly with the pen the conditions, manners, and sites of those holy places. And first I will begin with the holy church of Jerusalem and the indulgences that there are inside and out.

Ora mi bisognava senno e provedimento e buona memoria ad ciò ch'io potessi scrivere ordinatamente tutte le sancte luoghora i quali si sono d'oltra mare. Sicche quando io passai fu disposi nell'animo mio di non tornare giamai alla mia patria in prima ch'io non mi informasse interamente de tutte queste cose e luoghi deliberandomi di volere attentamente ad operare li cinque sentimenti del corpo cioèdi volere gustare odorare udire vedere e tocchare. Et domandare e cierchare dela verità e misurare a passi per lo longo o per lo traverso. Et poi tutto iscrivere e designare iuxta mio potere però che assai sono quelli li quali volonteri visitarebbono e cercharebbono quelli sancti luoghi. E chi non può per povertade alcuni non lo fanno per faticha o per tedio.Et anche che non si puote havere chessi dee havere dal papa. E cosìntendo di seguire sobrevita colla penna delle conditioni modi essiti di quelle sancte luoghora.Et in prima comminciarò della santa chiesa hierosolimitana e delle perdonanze che vi sono dentro e di fuora.

1500 Viazo da Venesia al Sancto Iherusalem (Petrucci and Petrucci, 9)

We will tell now of the orders of the holy church of Jerusalem. In order to follow these in order I need to have sense and foresight and good memory, and that which I can write and narrate of all the holy places which there are overseas, informing him who here reads that when I decided to enter into this voyage I was disposed and decided to not return ever into my country if first I truly had not notice to see, touch, and at the same time to ask of the truth and then to measure the palms and the spans [and] to measure for the length, for the width, and across, and then entirely to write everything; however there are enough people, who willingly would want to visit the holy places and who can not, who for poverty, who for fatigue, who for inconvenience and very often who can not have the word, or truly the 
permission, and this word and permission one must ask from the pope; and so recounting I want to write and briefly make note of these holy places. And first I will tell of this holy church of Jerusalem, and of the indulgence that there is inside and outside, and where one must look, and where the churches stand and are ordered, one after the other.

Diciamo ora degli ordini della sancta chiesia iherosolimitana. A volere seguitare questi ordinamenti me bisogna avere senno et antivedere et buona memoria, e ciò ch'io possa schrivere et narrare di tuti li sancti luoghi i quali sono holtra mare, avisando colui che qui leggie che quando diliberai d'entrare in questo viaggio mi dispuosi et proposimi di non tornare mai nella mia patria se in prima io veramente non avesse noticia di vedere, tochare et etiamdio di domandare della verità e poi per misura de palmi et di spanne misurare per lo longho, per lo largho et per lo traverso e poi intieramente scrivere il tutto, però ch'el ci è assai persone, i quali volentieri vorrebeno visitare i sancti luoghi et non possono, chi per povertà, chi per fatticha, chi per disasio e molte volte che non si può avere la parola, o vero la licentia, et questa parola et licenzia s'à a domandare al papa; e così seguitando lo voglio io scrivere et notifichare brievemente di questi sancti luoghi. Et in prima diremo di questa sancta chiesa iherosolimitana et della remisione che gli è dentro e di fuora e dove là è e dove là si dè cerchare e dove le chiese stanno et sono ordinate, l'una dopo l'altra.

\section{Viaggio da Venetia al Sancto Sepolchro (Poggibonsi, 1518, n.p.)}

We tell now of the order of the holy church of Jerusalem; wanting to recount these in order I need to have sense and foresight and good memory; in order that I could write and narrate all the holy places that are overseas; informing him who here reads, that when I decided to enter into the voyage, I was disposed and decided to not return ever into my country if not first I had truly noted [what there is] to see, to touch, and at the same time to ask of the truth and then for measure of palms and spans, to measure for the length and for the width, and across; and then entirely to write everything; rather that there are enough people who willingly would want to visit the holy places and cannot, who for poverty, who for fatigue, who for inconvenience very often cannot have the word or rather the permission, and this word and permission one has to ask from the pope; and thus recounting I want to write and briefly make note of these holy places; and first we will tell of the holy church of Jerusalem, and the indulgences that are there inside and outside, and where they are, and where one must look, and where the churches stand and [how they] are ordered, one after the other.

Diciamo hora de li ordini de la santa Chiesa hierosolimitana: a voler seguitare questi ordinamenti me bisogna haver senno e antiveder e bona memoria: aciò ch'io possa scriver e narrare $\&$ tutti li sancti lochi: i questi son oltra mare: avisando co'lui che qui legie: che quando deliberai d'entrar in questo viagio mi disposi e proposimi di non tornare mai nela mia patria se in prima io veramente non havesse notitia di 
vedere: toccare: e etiamdio di domandare de la verità e poi per misura de palmi e di spanne misurar per lo lungo e per lo largo: e per lo traverso: e poi interamente scriver il tutto: però che'l ci è assai persone: le qual volentiere vorrebbeno visitare li santi lochi e non possono: chi per povertà: chi per fatica: chi per disagione molte volte che non si può haver la parola: over la licentia: e questa parola e licentia se ha dimandar al Papa: e così seguitando lo voglio io scrivere e notificar brevemente di questi santi lochi: e in prima diremo de la sancta chiesa hierosolimitana: e la remissione che lì dentro e di fora: e dove la è: e dove la si dee cercare: e dove le chiese stanno e sono ordinate: l'una dopo l'altra. 


\section{Bibliography}

Amico, Bernardino. Trattato delle piante et imagini dei sacri edificii di terra santa. . . . Rome, 1609.

Amico, Bernardino. Plans of the sacred edifices of the Holy Land (Trattato delle piante et imagini dei sacri edificii di Terra Santa), engl. trans. from the Italian by Theophilus Bellorini, O.F.M. and Eugene Hoade, O.F.M. with a pref. and notes by Bellarmino Bagatti, O.F.M. Jerusalem, 1953.

Ascoli, Albert Russell. Dante and the Making of a Modern Author. Cambridge, 2008.

Betschart, Andres. Zwischen zwei Welten: Illustrationen in Berichten westeuropäischer Jerusalemreisender des 15. und 16. Jahrhunderts. Würzburg, 1996.

Bianco, Noe. Viaggio del r.p.f. Noe Bianco vinitiano della congregation de' servi, fatto in Terra Santa, \& descritto per beneficio de' pellegrini, \& de chi desidera hauere intera cognition de quei santi luogi. . . . Venice, 1566.

- Viaggio da Venetia al S. Sepolcro ed al monte Sinai . . prefazione di Sante Rossetto; introduzione e note storiche di Antonio Bozzetto. Salgareda, 2007.

Bonaventure, Saint. "Vitis Mystica," Or, the True Vine: A Treatise on the Passion of Our Lord: Ascribed to St. Bernard (more Recently to St. Bonaventure). London, 1873.

Bordone, Benedetto, and R. A. Skelton. Libro . . de tutte l'isole del mondo, Venice, 1528. Amsterdam, 1966.

Brefeld, Josephie. A Guidebook for the Jerusalem Pilgrimage in the Late Middle Ages. Hilversum, 1994.

Bryan, Michael, Robert Edmund Graves, and Walter Armonstrong. Dictionary of Painters and Engravers: Biographical and Critical. London, 1889.

Burke, Seán. The Death and Return of the Author: Criticism and Subjectivity in Barthes, Foucault and Derrida. Edinburgh, 1992.

Campbell, Mary B. Witness and the Other World: Exotic European Travel Writing, 400-1600. Ithaca, 1988.

Carruthers, Mary J. The Book of Memory: A Study of Memory in Medieval Culture. Cambridge, 1990.

Cooke, William R. "Prophecy in Stone: The Exterior Façade of the Basilica of St Francis of Assisi." The Art of the Franciscan Order in Italy, ed. William R. Cook, 71-93. Leiden, 2005.

Cossar, C. D. M. The German Translation of Niccolò da Poggibonsi's Libro d'Oltramare. Göppingen, 1985.

Davies, Hugh William. Bernhard von Breydenbach and His Journey to the Holy Land 1483-4: A Bibliography. London, 1911.

Demaray, John G. "Pilgrim Text Models for Dante's 'Purgatorio." Studies in Philology 66.1 (1969): 1-24.

Essling, Victor. Bibliographie des livres à figures vénetiens de la fin du $X V^{e}$ siècle et du commencement du $X V I^{e}$, 1469-1525. Vol. 1, pt. 2. Paris, 1892.

Essling, Victor, and Charles Gèrard. Ètudes sur l'art de la gravure sur bois à Venise: Les livres à figures vénetiens de la fin $d u$ $X V$ siècle et du commencement du XVI. Florence, 1907.

Flora, Holly. The Devout Belief of the Imagination: The Paris Meditationes Vitae Christi and Female Franciscan Spirituality in Trecento Italy. Turnhout, 2009.

Foucault, Michel. Language, Counter-Memory, Practice: Selected Essays and Interviews. Ithaca, 1980.

Frank, Georgia. The Memory of the Eyes: Pilgrims to Living Saints in Christian Late Antiquity. Berkeley, 2000. 
Golubovich, Girolamo. Biblioteca biobibliografica della Terra Santa e dell'Oriente francescano, dal 1346 al 1400. Rome, 1927.

Hamburger, Jeffrey F. "The Place of Theology in Medieval Art History: Problems, Positions, Possibilities." In The Mind's Eye: Art and Theological Argument in the Medieval West, ed. Jeffrey F. Hamburger and AnneMarie Bouché, 11-25. Princeton, 2005.

Hood, William. "The Sacro Monte of Varallo: Renaissance Art and the Growth of Vernacular Culture." In Monasticism and the Arts, ed. Timothy Gregory Verdon, 291-311. Syracuse, 1983.

Jeffrey, David L., "Franciscan Spirituality and the Growth of Vernacular Culture." In By Things Seen, Reference and Recognition in Medieval Thought, ed. David L. Jeffrey, 143-60. Ottawa, 1979.

Jongh, Henri de. "Les grandes lignes de l'histoire des indulgences." Vie diocesaine 6 (1912): 133-40.

Kup, Karl. The Christmas Story in Medieval and Renaissance Manuscripts from the Spencer Collection. New York, 1969.

Leatherbarrow, David. "The Image and Its Setting: A Study of the Sacro Monte at Varallo." RES: Anthropology and Aesthetics 14 (1987): 107-22.

Lehmann, Phyllis W. Cyriacus of Ancona's Egyptian Visit and Its Reflections in Gentile Bellini and Hieronymus Bosch. Locust Valley, 1977.

Litta, Pompeo. Celebri famiglie italiane. Milan, 1819.

Loewenstein, Joseph. The Author's Due: Printing and the Prehistory of Copyright. Chicago, 2002.

Lowden, John. "Treasures Known and Unknown in the British Library." http://www.bl.uk/catalogues/ illuminatedmanuscripts/TourKnownF. asp.
Ministero della pubblica istruzione. Indici e cataloghi. VII. I codici panciatichiani della biblioteca nazionale centrale di Firenze. Vol. 1, fasc. 1. Rome, 1887.

Montalboddo (fr. De). Paesi nouamente ritrouati per la Nauigatione di Spagna in Calicut Et da Albertutio Vesputio Fiorentino intitulato Mondo Nouo: Nouamente Impressa. Venice, 1517.

Moore, Kathryn Blair. "Textual Transmission and Pictorial Transformations: The Post-Crusade Image of the Dome of the Rock in Italy." Muqarnas: An Annual on the Visual Cultures of the Islamic World 27 (2010): 51-78.

Nardone, Jean-Luc. "Sept plances d'iconographie animalière dans le Viaggio da Venetia al Santo Sepulcro (1519)." Arches de Noé, I, Revue Italies, no. 10. Aix-en Provence, 2006, $37-56$.

Nardone, Jean-Luc, and Jacqueline Malherbe-Galy. La reprèsentation de Jerusalem et de la Terre sainte dans les rècits des pèlerins europèens au $X V I^{e}$ siècle. Paris, 2007.

Noonan, F. T. The Road to Jerusalem: Pilgrimage and Travel in the Age of Discovery. Philadelphia, 2007.

Odoardo, Giovanni. "La custodia francescana nel VI centennario della sua constituzione (1342-1942)." Miscellanea Francescana 43 (1943): 217-56.

Ostrow, Steven F. Art and Spirituality in Counter-Reformation Rome: The Sistine and Pauline Chapels in S. Maria Maggiore. Cambridge, 1996.

Petrucci, Armando, and Franca Petrucci. Viazo da Venesia al Sancto Iherusalem. Rome, 1972.

Poggi, Francesco, and Luigi Fiacchi. Viaggio al monte Sinai di Simone Sigoli; testo di lingua citato nel Vocabulario ed ora per la prima volta pubblicato con due lezioni sopra il medesimo. Florence, 1829. 
Poggibonsi, Niccolò. Libro d'Oltramare.

BNCF II. IV. 101. Biblioteca Nazionale, Florence.

Libro d'Oltramare. Ms.

Panciatichi 78. Biblioteca Nazionale,

Florence.

- Libro d'Oltramare. Ms. Panciatichi

79. Biblioteca Nazionale, Florence.

- Libro d'Oltramare (anonymous

version). NYPL Spencer 62. Spencer

Collection, New York Public Library.

- Libro d'Oltramare (anonymous

German translation). BL Egerton

1900. British Library, London.

- Viazo da Venesia al Sancto

Iherusalem et al Monte Sinai.

Bologna: Iustiniano da Rubiera, 1500.

- Viaggio da Venetia al Sancto

Sepolchro et al Monte Sinai. Venice:

Nicolo detto Zoppino, 1518.

- Viaggio da Venezia al Sancto

Sepolchro et al Monte Sinai. Venice:

Tacuino da Trino, 1520.

- Viaggio da Venezia al Sancto

Sepolchro et al Monte Sinai. Venice:

Niccolò detto Zoppino and Vincentio

Compagno, 1524.

- Viaggio da Venetia al Santo

Sepulchro e al Monte Synai. Venice:

Giovanni Tacuino de Trino, 1538.

- Viaggio da Venezia al Sancto

Sepolcro et al Monte Sinai. Treviso:

Antonio Paluello, 1600.

- Viaggio da Venetia al Sancto

Sepolchro et al Monte Sinai. Venice:

Alessandro de' Vecchi, 1606.

- Viaggio da Venetia al Santo

Sepolcro et al Monte Sinai. Venice:

Ghirardo Imberti, 1640.

- Viaggio da Venetia al Sancto

Sepolcro et al Monte Sinai. Venice: presso i Milochi, 1647.

- Viaggio da Venetia al Sancto

Sepolcro et al Monte Sinai. Venice:

Domenico Lovisa, 1690.

- Viaggio da Venezia al Santo

Sepolcro ed al Monte Sinai. Treviso:

Antonio Paluello, 1800.
—. Libro d'Oltramare di Fra Niccolò da Poggibonsi pubblicato da Alberto Bacchi della Lega. Bologna, 1881.

- A Voyage beyond the Seas (1346-1350). Trans. T. Bellorini and Eugene Hoade. Jerusalem, 1945a.

- Libro d'Oltramare, 1346-1350.

Testo di A. Bacchi della Lega riveduto e rannotato dal P. B Bagatti. Jerusalem, 1945 b.

Quint, David. Origin and Originality in Renaissance Literature: Versions of the Source. New Haven, 1974.

Röhricht, Reinhold. Bibliotheca geographica Palaestinae: chronologisches Verzeichniss der auf die Geographie des Heiligen Landes bezuglichen Literatur von 333 bis 1878 und Versuch einer Cartographie. Berlin, 1890.

Roncière, Charles Bourel de La. "Società locali e ordini mendicanti nella Valdelsa fiorentina nel Trecento (1300-1370)." In Gli ordini mendicanti in Valdelsa (Convegno di Studio, Colle Val d'Elsa, Poggibonsi, San Gimignano, 6-7-8 June 1996, 233-58. Vol. 15, Biblioteca della "Mescellanea storica della Valdesa." Castelfiorentino, 2000.

Rosenthal, Erwin. "The Crib of Greccio and Franciscan Realism." The Art Bulletin 36.1 (1954): 57-60.

Rudy, Kathryn M. Virtual Pilgrimages in the Convent: Imagining Jerusalem in the Late Middle Ages. Turnhout, 2011.

Sandoli, Sabino De. Itinera Hierosolymitana Crucesignatorum: Saec. XII-XIII: Textus Latini cum Versione Italica. 4 vols. Jerusalem, 1978.

Sarchi, Alessandra. "The studiolo of Alberto Pio da Carpi." In Drawing Relationships in Northern Italian Renaissance Art: Patronage and Theories of Invention, ed. Giancarla Periti, 129-46. Aldershot, 2004.

Serra-Zanetti, Alberto. L'arte della stampa in Bologna: nel primo ventennio del cinquecento. Bologna, 1959. 
$\rightarrow$ Spitzer, Leo. "Note on the Poetic and the Empircal 'I' in Medieval Authors." Traditio 4 (1946): 414-22.

Thompson, E. M. An Introduction to Greek and Latin Paleography. Oxford, 1912.

Tobler, Titus. Bibliographica geographica Palestinae. Zunachst kritische uebersicht gedruckter und ungedruckter beschreibungen der reisen ins Heilige Land. Leipzig, 1867.
Warner, Nicholas, Matheo Pagano, and Guillaume Postel. The True Description of Cairo: A SixteenthCentury Venetian View. London, 2006.

Wharton, Annabel Jane. Selling Jerusalem: Relics, Replicas, Theme Parks. Chicago, 2006.

Wilkinson, John. Jerusalem Pilgrims before the Crusades. Warminster, 2002. 